Review

\title{
RFamide Peptides: Structure, Function, Mechanisms and Pharmaceutical Potential
}

\author{
Maria Findeisen ${ }^{\dagger}$, Daniel Rathmann ${ }^{\dagger}$ and Annette G. Beck-Sickinger * \\ Institute of Biochemistry, Leipzig University, Brüderstraße 34, 04103 Leipzig, Germany; \\ E-Mails: mfind@uni-leipzig.de (M.F.); rathmann@uni-leipzig.de (D.R.) \\ $\dagger$ These authors contributed equally to this work. \\ * Author to whom correspondence should be addressed; E-Mail: beck-sickinger@uni-leipzig.de; \\ Tel.: +49-341-9736900; Fax: +49-341-9736909.
}

Received: 29 August 2011; in revised form: 9 September 2011 / Accepted: 15 September 2011 / Published: 21 September 2011

\begin{abstract}
Different neuropeptides, all containing a common carboxy-terminal RFamide sequence, have been characterized as ligands of the RFamide peptide receptor family. Currently, five subgroups have been characterized with respect to their N-terminal sequence and hence cover a wide pattern of biological functions, like important neuroendocrine, behavioral, sensory and automatic functions. The RFamide peptide receptor family represents a multiligand/multireceptor system, as many ligands are recognized by several GPCR subtypes within one family. Multireceptor systems are often susceptible to cross-reactions, as their numerous ligands are frequently closely related. In this review we focus on recent results in the field of structure-activity studies as well as mutational exploration of crucial positions within this GPCR system. The review summarizes the reported peptide analogs and recently developed small molecule ligands (agonists and antagonists) to highlight the current understanding of the pharmacophoric elements, required for affinity and activity at the receptor family. Furthermore, we address the biological functions of the ligands and give an overview on their involvement in physiological processes. We provide insights in the knowledge for the design of highly selective ligands for single receptor subtypes to minimize cross-talk and to eliminate effects from interactions within the GPCR system. This will support the drug development of members of the RFamide family.
\end{abstract}


Keywords: RFamide; neuropeptide FF; kisspeptin; prolactin-releasing peptide; QRFP

\section{Introduction}

Neuropeptides characterized by a common carboxy-terminal arginine $(\mathrm{R})$ and an amidated phenylalanine (F) motif (designated RFamide peptides) were originally discovered in invertebrates [1]. In mammals it is now known that there exist at least five genes, encoding the family members and the five G-protein coupled receptors through which RFamide peptides act. All these peptides show a great diversity, regarding their N-termini and hence a wide pattern of biological activity.

The initially identified tetrapeptide FMRFamide was isolated from the ganglia of the clam as a cardioexcitatory peptide [1]. Significant improvements in the molecular characterization of the RFamide peptide system have been made since then. Nowadays the rising number of RFamide peptides found in mammals can be subdivided into five groups: the neuropeptide FF (NPFF) group, the gonadotropin-inhibitory $(\mathrm{GnIH})$ group, the 26RFa group, the kisspeptin/metastin group and the prolactin-releasing peptide (PrRP) group. By applying a reverse pharmacological method and by searching of DNA sequence databases several other structurally similar peptides have also been identified (Table 1). The first reported vertebrate member was LPLRFamide [2], and the first mammalian RFamide peptides were neuropeptide FF and neuropeptide AF [3]. Both were purified from bovine brain extracts [3], showed several biological activities in vivo in mammals [4] and are encoded by a single gene [5]. GnIH homologs were isolated from extracts of the human hypothalamus by immunoaffinity purification, and furthermore identified as human RFamide-related peptide 1 (RFRP-1) and human RFRP-3 by mass spectrometry [6]. Both, 26RFa and the longer form of 26RFa, termed 43RFa (QRFP), have been isolated from the human hypothalamus and spinal cord [7].

Table 1. Comparison of amino acid sequences of endogenous RFamide peptides in human.

\begin{tabular}{|c|c|c|c|}
\hline Group & Peptide & Sequence & Ref. \\
\hline \multirow{2}{*}{ NPFF group } & NPFF & SQAFLFQPQRF-NH ${ }_{2}$ & {$[5]$} \\
\hline & NPAF & AGEGLNSQFWSLAAPQRF-NH $_{2}$ & [5] \\
\hline \multirow{2}{*}{ GnIH group } & RFRP-1 (NPSF) & MPHSFANLPLRF-NH ${ }_{2}$ & {$[6,13]$} \\
\hline & RFRP-3 (NPVF) & VPNLPQRF-NH ${ }_{2}$ & {$[6,13]$} \\
\hline \multirow[t]{2}{*}{ 26RFa group } & 43RFa (QRFP) & $\begin{array}{r}<\text { EDEGSEATGFLPAAGEK- } \\
\text { TSGPLGNLAEELNGYSRKKGGFSFRF-NH }\end{array}$ & {$[7,14]$} \\
\hline & 26RFa & TSGPLGNLAEELNGYSRKKGGFSFRF-NH $_{2}$ & {$[7,14]$} \\
\hline \multirow[t]{2}{*}{ PrRP group } & PrRP31 & $\begin{array}{r}\text { SRTHR- } \\
\text { HSMEIRTPDINPAWYASRGIRPVGRF-NH }\end{array}$ & {$[8,9]$} \\
\hline & PrRP20 & TPDINPAWYASRGIRPVGRF-NH ${ }_{2}$ & {$[8,9]$} \\
\hline \multirow{4}{*}{ Kisspeptin group } & kisspeptin-54 & $\begin{array}{l}\text { GTSLSPPPESSGSRQQPGLSAPHSRQI- } \\
\text { PAPQGAVLVQREKDLPNYNWNSFGLRF-NH }\end{array}$ & {$[10,15]$} \\
\hline & kisspeptin-14 & DLPNYNWNSFGLRF-NH ${ }_{2}$ & {$[10,15]$} \\
\hline & kisspeptin-13 & LPNYNWNSFGLRF-NH ${ }_{2}$ & {$[10,15]$} \\
\hline & kisspeptin-10 & YNWNSFGLRF-NH & {$[10,15]$} \\
\hline
\end{tabular}

Pyroglutamic acid is shown as $<\mathrm{E}$. 
PrRP was identified in 1998 by a reverse pharmacology approach [8]. Up to now two equipotent isoforms of different N-terminal length are known, PrRP31 and PrRP20 [9]. The naturally occurring kiss RFamide peptides, consisting of 54-, 14-, or 13-amino acids were isolated from human placenta [10], whereas the highly potent kisspeptin-10 was synthesized [14]. Due to the prediction that all three endogenous peptides derive from KiSS-1 [11], a metastasis suppressor gene for melanoma cells, they were designated as kisspeptins. It should be noted that Hori et al. [12] named the same peptide metastin, which derives from its initially discovered function to suppress metastasis, but for clarity kisspeptin is used preferentially in this review.

\section{RFamide Peptide Receptor Family}

Several orphan receptors turned out to respond to different members of the RFamide peptide family (Table 2). The PrRP receptor was the first putative RFamide receptor that was identified and initially described as GPR10 [8]. In 2000, the putative receptors for NPFF and NPAF were identified and named NPFF1/GPR147 and NPFF2/GPR74 [13,16,17]. Independently, two groups could show that both, $26 \mathrm{RFa}$ and 43RFa, act as natural ligands of the orphan receptor GPR103 [18,19]. The kisspeptin receptor or KiSS1-derived peptide receptor was formerly discovered as orphan G-proteincoupled receptor GPR54 [20,22]. For the explanations that follow we refer to the protein names of the corresponding receptors (Table 2).

Table 2. Overview of putative RFamide receptors in human.

\begin{tabular}{|llcc|}
\hline Ligand & Protein names & Known gene names & Ref. \\
\hline $\begin{array}{l}\text { RFRP-1 (NPSF), } \\
\text { RFRP-3 (NPVF) }\end{array}$ & Neuropeptide FF receptor 1 $\left(\mathrm{NPFF}_{1} \mathrm{R}\right)$ & $\begin{array}{c}\text { NPFR1 GPR147, } \\
\text { NPFF1 }\end{array}$ & {$[13,16]$} \\
\hline NPFF, NPAF & Neuropeptide FF receptor 2 $\left(\mathrm{NPFF}_{2} \mathrm{R}\right)$ & $\begin{array}{c}\text { NPFFR2 } \\
\text { GPR74, NPFF2 }\end{array}$ & {$[16,17,21]$} \\
\hline 43RFa (QRFP), & Pyroglutamylated RFamide peptide receptor & QRFPR & {$[18,19]$} \\
26RFa & QRFPR) & GPR103 & KISS1R AXOR12, \\
\hline Kisspeptins & Kisspeptin receptor & GPR54 & {$[20,22]$} \\
\hline PrRP31, PrRP20 & Prolactin-releasing peptide receptor (PrRPR) & PRLHR & {$[8]$} \\
\hline
\end{tabular}

So far there are only few mutagenesis data available. We decide to focus on one residue on the top of transmembrane helix (TMH) 6, which is known to be present and/or important for receptor activation in several related receptor families (e.g. the NPY receptor family). Because all ligands share an amidated dipeptide motif at their C-termini with the positively charged arginine side chain, an acidic residue has been proposed to act as a counterpart. Therefore, first investigations were made on an acidic residue 6.59 on the top of TMH 6, according to the nomenclature of Ballesteros and Weinstein [23].

\subsection{Neuropeptide FF Receptor 1 (GPR147)}

It was recently shown by immunohistochemistry that cells expressing the human $\mathrm{NPFF}_{1} \mathrm{R}$ are localized in the human hypothalamus and surrounding areas [24]. It is now clear, that most human 
forebrain nuclei contain such cells, supporting the idea that RFamide peptides play a role in central coordination of neuroendocrine and autonomic responses in humans. The $\mathrm{NPFF}_{1} \mathrm{R}_{\text {commonly activates }}$ the $\mathrm{G}_{\mathrm{i} / \mathrm{o}}$ signal transduction pathway $[13,16]$. The human receptor was isolated from a human spinal cord cDNA library and analysis by sequencing led to a coding sequence of $1290 \mathrm{bp}$, and a predicted protein with a length of 430 amino acids [16]. Comparing the primary sequence of human $\mathrm{NPFF}_{1} \mathrm{R}$ with other known GPCRs showed, that $\mathrm{NPFF}_{1} \mathrm{R}$ is most similar to human orexin1 (37\% identity), human orexin2 (35\%), human neuropeptide $\mathrm{Y}$ receptor subtype 2 (NPY $\left.{ }_{2} \mathrm{R}\right)(34 \%)$, human chole-cystokinin A (CCKA) (34\%), human $\mathrm{NPY}_{1} \mathrm{R}$ (32\%), mouse GIR (32\%), human prolactin-releasing hormone receptor (32\%), and human NPY ${ }_{4} \mathrm{R}(31 \%)$ [16]. RFRP-1 and RFRP-3 efficiently inhibit production of forskolin-induced cAMP accumulation in CHO cells, expressing the human $\mathrm{NPFF}_{1}$ receptor [13]. Furthermore, pharmacological characterization of $\mathrm{hNPFF}_{1}$-transfected SH-SY5Y cells was performed by measuring the intracellular cAMP content [25]. By using a $\left[{ }^{35} \mathrm{~S}\right] \mathrm{GTP} \gamma \mathrm{S}$ binding assay, the functional activities of RFamide peptides were investigated in $\mathrm{CHO}$ cells stably expressing the $\mathrm{NPFF}_{1}$ receptor [26].

To the best of our knowledge, there is just one receptor mutant published so far. In studies regarding the related NPY receptor family, Merten et al. could clearly demonstrate that the acidic residue 6.59 on the top of TMH 6 plays an important role in ligand binding [27]. Thus, Findeisen et al. presumed a strong ionic interaction to be involved in ligand recognition and receptor activation at position 6.59. When the derived $\mathrm{Asp}^{6.59}$ mutants were investigated [28], the introduction of an elongated charge conserving glutamate revealed a minor loss in receptor activation, whereas the replacement of Asp with Ala or Asn led to a significant loss in affinity and receptor activation. The need for a negatively charged side chain at position 6.59 is underlined by the introduction of Arg, resulting in strongly decreased affinities and a not fully activatable $\mathrm{hNPFF}_{1} \mathrm{R}$ mutant. Another part of the binding pocket is proposed to be built up by residues located in the upper sections of the TMHs. Further investigations revealed evidence that other hydrophobic residues are not involved in a direct interaction. By mutating putative residues of impact to alanine, we merely found a minor loss of receptor activation for Phe ${ }^{5.43}$, $\mathrm{Phe}^{7.37}$, Phe ${ }^{7.44}$ (unpublished data).

\subsection{Neuropeptide FF Receptor 2 (GPR74)}

By autoradiography and by the use of a radiolabelled NPFF analog, $\left[{ }^{125} \mathrm{I}\right](1 \mathrm{DMe})$ Y8Famide, it could be shown that NPFF receptors are localized in the central nervous system $[29,30]$. The $\mathrm{NPFF}_{2} \mathrm{R}$ mostly activates the $\mathrm{G}_{\mathrm{i} / \mathrm{o}}$ signal transduction pathway $[16,17]$. The human full-length receptor was amplified from spinal cord cDNA and further analysis by sequencing led to a coding sequence of $1260 \mathrm{bp}$, and a predicted protein with a length of 420 amino acids [16]. Both NPFF receptors share $50 \%$ amino acid identity. Pharmacological characterization of human $\mathrm{NPFF}_{2}$ receptor was performed by measuring the cAMP levels in CHO cells as well as in HEK293 cells transfected with $\mathrm{hNPFF}_{2} \mathrm{R}$ [17]. Furthermore, the anti-opioid effects on $\mathrm{Ca}^{2+}$ mobilization were investigated by measuring $\mathrm{Ca}^{2+}$ contents in SH-SY5Y cells transfected with the human $\mathrm{NPFF}_{2} \mathrm{R}$ [31]. Additionally, the $\left[{ }^{35} \mathrm{~S}\right] \mathrm{GTP} \gamma \mathrm{S}$ binding was studied in CHO cells stably expressing the human $\mathrm{NPFF}_{2} \mathrm{R}$ [26].

To compare the receptor subtype specific activation the same acidic residue on the top of TMH 6 was investigated by Findeisen et al. [28]. The introduction of glutamate at position 6.59 revealed an 
equipotent minor loss in $\mathrm{NPFF}_{2} \mathrm{R}$ activation as for $\mathrm{NPFF}_{1} \mathrm{R}$. Regarding NPFF receptor subtype selectivity the modifications of Asp to Asn and Ala was better tolerated at the $\mathrm{hNPFF}_{1} \mathrm{R}$, compared to the $\mathrm{hNPFF}_{2} \mathrm{R}$. This clearly indicates that the $\mathrm{hNPFF}_{2} \mathrm{R}$ is more sensitive at this receptor site. The replacement of $\mathrm{Asp}^{6.59}$ with Arg resulted in a not fully activatable $\mathrm{hNPFF}_{2} \mathrm{R}$ variant, which demonstrates the necessity of a negatively charged amino acid. Further investigations regarding hydrophobic residues in the upper transmembrane regions revealed no involvement in receptor activation. By mutating residues of interest to alanine we could see no loss of receptor activation at position $\mathrm{Phe}^{5.43}$ or $\mathrm{Phe}^{7.40}$ (unpublished data).

\subsection{Pyroglutamylated RFamide Peptide Receptor (GPR103)}

The QRFP receptor is an orphan G-protein coupled receptor and was originally cloned from a human brain cDNA library. It has been detected widely throughout the brain, heart, kidney, retina and testis [19]. GPR103 encoded a 455 amino acid protein and phylogenetic analysis showed that the orphan receptor shares identities with peptide-binding receptors, including $\mathrm{NPFF}_{2} \mathrm{R}, \mathrm{NPY}_{2} \mathrm{R}$ and galanin GalR1 receptors (34-38\% in the TM regions). The QRFPR commonly activates the $\mathrm{G}_{\mathrm{q}} / \mathrm{G}_{\mathrm{i}}$ signal transduction pathway. With regards to the conserved acidic residue at position 6.59 , a glutamate is present instead of an aspartate. Nevertheless, by the replacement with alanine, we could see the same loss ( $\sim 60$-fold) in activity as for the $\mathrm{NPFF}_{1} \mathrm{R}$ (unpublished data). Replacement of a hydrophobic residue $\left(\mathrm{Phe}^{5.41}\right.$ ) by alanine revealed no involvement in receptor activation since no decreased $\mathrm{EC}_{50}$-value was detected (unpublished data).

\subsection{Kisspeptin/Metastin Receptor (GPR54)}

The kisspeptin receptor was originally cloned from rat brain, sharing $45 \%$ identity with the galanine receptors [22]. In humans, reverse transcriptase polymerase chain reaction has revealed, that GPR54 was highly expressed in placenta, pituitary, pancreas, and spinal cord, suggesting an important role in the regulation of endocrine function [10,15]. Furthermore, by immunohistochemistry kisspeptin receptor protein expression was detected in the cerebral cortex, thalamus, pons-medulla and cerebellum [20]. Together with the use of radioligand binding Mead et al. found expression in aorta, coronary artery and umbilical vein [32]. Functional assays were performed in $\mathrm{CHO}$ cells transfected with the kisspeptin receptor [12] and in vitro pharmacology was carried out by using human isolated vessels [32]. Up to now it is known that the activated kisspeptin receptor acts via $\mathrm{G}_{\mathrm{q}} / \mathrm{G}_{11}$ signal transduction pathways, leading to the stimulation of phospholipase $\mathrm{C}$ and consequently to calcium mobilization. Additionally, activation of the kisspeptin receptor has been shown to stimulate arachidonic acid release [10].

While the acidic residue 6.59 is conserved throughout the whole RFamide peptide receptor family, in the human kisspeptin receptor an alanine is present at that position. To our knowledge, no mutational studies have been performed so far. It should be noted that by using polymorphism scanning and typing of KiSS-1/GPR54 gene, Chu et al. recently unveiled a couple of harmful polymorphisms [33]. This includes the mutation of residue Phe in position 272 to Ser in the GPR54 gene, a loss-of-function mutant, which is associated with familial normosmic IHH (idiopathic hypogonadotropic hypogonadism) [34]. Underdeveloped external genitalia and impuberism point to the major role of GPR54 in the activation of the gonadotropic axis from intrauterine life to adulthood [34]. 


\subsection{Prolactin-Releasing Peptide Receptor (GPR10)}

The prolactin-releasing peptide receptor was originally isolated from rat hypothalamus [35] but has been detected widely throughout the human and rat brain [36]. After binding of the endogenous ligand the activated receptor most commonly activates the $\mathrm{G}_{\mathrm{q}}$ signal transduction pathway [9].

The only manuscript concerning mutagenesis studies which is published so far reports that the PrRP receptor has a PDZ domain binding motif in its C-terminal tail (-SVVI) [37]. In a mutational study with the prolactin releasing peptide receptor we were able to show the involvement of the aspartic residue at position 6.59 (unpublished data). By replacement with alanine, a 22-fold loss of receptor activity upon stimulation with PrRP was observed. As mentioned above a second part of the binding pocket is proposed to be built up by residues, located in the upper sections of the transmembrane helices. Therefore, in a first study we investigated the involvement of hydrophobic residues. We could not detect a decreased $\mathrm{EC}_{50}$-value, when $\mathrm{Phe}^{2.72}$, Trp ${ }^{5.40}$, $\mathrm{Phe}^{7.31}$ or $\operatorname{Trp}^{7.40}$ was mutated to alanine upon stimulation, which revealed no involvement in ligand binding and receptor activation (unpublished data).

\section{Physiological Effects of RFamide Peptides}

\subsection{Neuropeptide FF}

NPFF was initially identified to attenuate morphine induced antinociception and to evoke an increased sensitivity to pain, called hyperalgesia $[3,38]$. Since then, the range of activities has been expanded and is associated with a plethora of physiological and behavioral phenomena. In rats, NPFF was shown to participate in the modulation of the cardiovascular system, basically inducing increased blood pressure, bradycardia or inhibition of the cardiac component of the baroreceptor reflex [39-45]. Further studies revealed an anorectic impact of NPFF in rats [46,47] and in chicken [48] but also NPAF [49] and NPSF [50] showed reduced food consumption in chicken. This effect on food consumption is generally described for almost all RFamide peptides in several vertebrates [51,52]. Furthermore, NPFF is known to be involved in water balance [47,53,54] and with NPSF and NPAF affects adipogenesis [55]. Moreover recent investigations in rodents describe NPFF to be involved in locomotion and reward [56-59]. Central injections of NPFF in mice evoked hypothermic effects [60-62] and could be antagonized by BIBP3226 as well as by RF9 $[63,64]$. No intrinsic affinity at any of the opioid receptors subtypes was observed for NPFF $[4,65,66]$, nevertheless NPFF has been recognized as an effective modulator of opioid functions and pain. Additionally, NPFF was found to take part in the development of opiate tolerance and dependence [67,68], albeit the observed anti-/pro-opioid effects of NPFF are dependent on the site of administration [38,69].

\section{2. $\operatorname{PrRP}$}

PrRP has been initially identified as a prolactin-releasing factor [8] but follow-up studies rather suggest that the major effects of this neuropeptide are different. In rodents, PrRP is involved in the control of body weight homeostasis inducing anorexia but it has, in contrast to NPFF, no impact on locomotion, exploratory time, grooming and resting time [70,71]. Further studies revealed evidence for a role of PrRP as a regulator for stress response [72-74], nociception [74], and the cardiovascular system, 
i.e. arterial blood pressure [75]. PrRP effects were additionally described to be mediated by the NPFF receptor system in vivo and in vitro [76] but also via the corticotropin releasing hormone system [77], which is involved in the mediation of cardiovascular [78] or anorectic effects [79].

\subsection{Kisspeptin/Metastin}

Due to its implication as a suppressing factor for metastasis, the processed 54 amino acid peptide kisspeptin was originally named metastin [10-12,15]. The role of the kisspeptin/metastin encoding Kiss 1 gene in cancer metastasis has been recently reviewed [80]. The common perception of metastin/kisspeptins as pivotal regulator for reproduction [81-84] was the inception for a plethora of studies in this field. Either central or peripheral administration of the peptides kisspeptin-54 and/or kisspeptin-10 were identified to stimulate the gonadotropin-releasing hormone $(\mathrm{GnRH})$, luteinizing hormone ( $\mathrm{LH})$, follicle-stimulating hormone (FSH), and testosterone secretion [81-84]. Furthermore, the importance of the kisspeptin receptor GPR54 was elucidated as some cases of hypogonadotopic hypogonadism were associated with mutations of the GPR54 gene [85-87]. Mice, lacking the gene of the receptor fail to undergo sexual maturation [86]. In contrast to the other RFamide peptides, kisspeptin/GPR54 is not directly involved in body weight control and food consumption [86,88]. It was only described to reduce food consumption by increasing the meal intervals in mice [89] or the reduced hypothalamic expression of kisspeptin itself was observed for leptindeficiencyanddiet-induced obesity in mice [90]. The multiple physiological functions of the kisspeptin/kisspeptin receptor signaling as a nodal point in the neuroendorinical regulation of puberty and reproduction [91] have been recently reviewed and are not focus of the present review [92-95].

\section{4. $G n I H$}

The name of the gonadotrophin-inhibitory hormone already describes the initially discovered function for the RFamide related peptide, which was discovered in 2001 in quail brains [96]. Further exploration identified the mammalian orthologs of the avian GnIH, called RFamide related peptide-1, -2 or -3 (RFRP-1, -2, and -3) and their functional roles. RFRP-3 application in rodents confirmed the inhibitory effects on GnRH neurons [97] and further investigations suggest an inhibitory modulation of GnRH stimulated LH secretion at the pituitary [98,99]. But RFRP-3 has also a strong influence on feeding and sexual behavior in rats [100]. In ovine, RFRP-3 was shown to project to cells being involved in regulation of energy balance and reproduction [101]. For clarification, it has to be emphasized that the human RFRP-3 shares the same sequence with the ovine RFRP-3 and more importantly, it is also designated as NPVF in humans. Previous investigations reported NPVF as $\mathrm{NPFF}_{1} \mathrm{R}$ selective agonist, which attenuate morphine-induced antinociception more effective than NPFF. Furthermore, NPVF is suggested to be important for the endogenous anti-opioid mechanism [25,102,103]. The hyperthermic effects of NPVF resemble those of NPFF [62,63]. In chicken, NVPF regulates appetite in a short term manner and its effects are related with hypothalamic and behavior changes [104]. The NPVF-induced satiety was shown to be mediated through $\mu$ and $\kappa$ but not $\delta$ subtypes of opioid receptors in chicken [105]. 


\section{5. $43 R F a(Q R F P) / 26 R F a$}

The latest member of the RFamide peptides, $26 \mathrm{RFa}$ or $43 \mathrm{RFa}$ (QRFP) demonstrates a variety of different physiological processes to be involved in, such as regulation of the cardiovascular system by elevating the arterial blood pressure and the heart rate in rodents [106,107]. Administration of either 26RFa or QRFP plays an important role in energy homeostasis by regulating the appetite and energy expenditure, finally resulting in obesity with hyperphagia [14,107-110]. Additionally, both ligands possess the ability to activate the gonadotropic axis [111,112] and can increase locomotor activity [107,109]. Recent data present 26RFa able to produce an analgesic effect [113] and to modulate the nociceptive transmission, finally evoking anti-allodynic effects [114]. Furthermore, $26 \mathrm{RFa}$ is suggested to promote bone formation [115]. This is suggested by the identification of the 26RFa gene as a potential osteoporosis gene [116].

\section{Structure-Activity and Structure-Affinity Studies}

A common approach to identify the most important segment of a ligand is to determine the minimal sequence, which is required to activate the receptor. To note, the first described structure-activity study of an RFamide peptide on molluscan muscle revealed that FMRF-OH retained 1/100th of the activity of FMRFamide, while MRFamide had 1/1000th [1]. Thus, the amidation as well as a certain peptide length had to be considered for future SAR studies at vertebrates. Indeed, the amidated C-terminal fragment of the ligand family is essential for all receptors within this family. Structure-affinity/activity relationship studies can be used to characterize the interaction between ligand and receptor. Essential segments of the peptide and essential segments of the receptor for the interaction can be identified and distinguished from non-essential residues. Furthermore, the investigation of the three-dimensional structure of biologically active peptides is important for the clarification of structure-activity relationships and thus for the development of potent agonists and antagonists [117].

\subsection{SAR of NPFF Analogs}

Many modifications of the NPFF sequence on the N-terminus and the C-terminus have been performed [118,119]. The affinities of NPFF-related peptides inhibiting $\left[{ }^{125} \mathrm{I}\right] 1 \mathrm{DME}$ or $\left[{ }^{125} \mathrm{I}\right]\left[\mathrm{Tyr}^{1}\right]$ NPFF specific binding in the dorsal horn of rat spinal cord are summarized in Table 3. First investigations clearly showed that neither an acetylated N-terminus nor deletion of the two N-terminal residues (not shown) significantly modified peptide affinity [118,119]. In contrast, NPFF(4-8) and NPFF(5-8) showed a 100-fold reduced affinity compared to NPFF. Further on, the carboxy-terminal tripeptide itself (Gln-Arg-Phe- $\left.\mathrm{NH}_{2}\right)$ had only a weak affinity $\left(\mathrm{K}_{\mathrm{i}}\right.$ of $\left.300 \pm 45 \mathrm{nM}\right)$ [118,119]. The introduction of the $D$-enantiomer at position 5 reduced the affinity 100 -fold. Accordingly, the most important part is the RFamide motif. Substitutions at position 7 or 8 are not well tolerated and reduced the affinity dramatically. Only substitution to $D$-Arg in position 7 or Tyr in position 8 showed a moderate loss of affinity about 100-fold compared to NPFF $[118,119]$. Double substitution of $\operatorname{Arg}^{7}$ and $\mathrm{Phe}^{8}$ by the corresponding enantiomer $\left(D-\mathrm{Arg}^{7}\right.$ and $\left.D-\mathrm{Phe}^{8}\right)$ significantly reduced the affinity. The amidated C-terminus is as important as the last two residues. The free acid containing peptide does not show any significant potency compared to the amidated form $[118,119]$. 
The classic strategy of amino acid substitution and deletion could clarify the structural requirements for binding to the NPFF receptors. Since then, signal transduction assays were performed in combination with binding experiments on recombinantly expressed NPFF receptor subtypes. The data in Table 4 provide information about the receptor subtype specificity, with regards to the pro-NPFF $F_{A}$ and pro-NPFF ${ }_{B}$ derived peptides. These two precursors generate different RFamide peptides. It has been suggested that peptides derived from pro- $\mathrm{NPFF}_{\mathrm{A}}$ display high affinity/activity at the $\mathrm{NPFF}_{2} \mathrm{R}$ and, conversely, peptides from pro- $\mathrm{NPFF}_{\mathrm{B}}$ precursor show slight preference for the $\mathrm{NPFF}_{1} \mathrm{R}$ [102]. Data are similar between the different functional assays and confirm that RFRP-3 (NPVF) and RFRP-1 (NPSF) are more active at the $\mathrm{NPFF}_{1} \mathrm{R}$ than NPFF and NPAF. In accordance with other data, the opposite behavior was found at the $\mathrm{NPFF}_{2} \mathrm{R}$ for NPFF, NPAF and RFRP-3, RFRP-1. Furthermore, shortening the $\mathrm{NPFF}$ sequence clearly underlines that these modifications are better tolerated at the $\mathrm{NPFF}_{2} \mathrm{R}$. And vice versa modifications in the RFRP-3 and RFRP-1 sequence show greater effects at $\mathrm{NPFF}_{1} \mathrm{R}[28,120,121]$. In contrast, by ending up in the tetrapeptide PQRF- $\mathrm{NH}_{2}$ the same behavior is displayed for both receptors $[28,120,121]$. This is not surprising because of the equal carboxy-terminal four amino acids.

Table 3. Affinities of NPFF-related peptides determined in the dorsal horn of the rat spinal cord $[118,119]$.

\begin{tabular}{|c|c|c|}
\hline NPFF derived analogs & Sequence & $\begin{array}{c}\text { NPFF receptors }{ }^{a} \\
K_{i}[\mathbf{n M}]\end{array}$ \\
\hline NPFF & F-L-F-Q-P-Q-R-F-NH ${ }_{2}$ & $0.34 \pm 0.07$ \\
\hline$[\mathrm{N}-\mathrm{Ac}] \mathrm{NPFF}$ & acetyl-F-L-F-Q-P-Q-R-F-NH 2 & $0.74 \pm 0.16$ \\
\hline NPFF(4-8) & Q-P-Q-R-F-NH 2 & $20.9 \pm 3.1$ \\
\hline $\operatorname{NPFF}(5-8)$ & $\mathrm{P}-\mathrm{Q}-\mathrm{R}-\mathrm{F}-\mathrm{NH}_{2}$ & $15.5 \pm 2.3$ \\
\hline NPFF(6-8) & Q-R-F-NH 2 & $300 \pm 45$ \\
\hline$\left[\mathrm{Tyr}^{1} ; D\right.$-Pro $\left.{ }^{5}\right] \mathrm{NPFF}$ & Y-L-F-Q-[D-Pro]-Q-R-F-NH 2 & $30.0 \pm 4.0$ \\
\hline$\left[\mathrm{Lys}^{7}\right] \mathrm{NPFF}$ & F-L-F-Q-P-Q-Lys-F-NH & $245 \pm 90$ \\
\hline$\left[D-\mathrm{Arg}^{7}\right] \mathrm{NPFF}$ & F-L-F-Q-P-Q-[D-Arg]-F-NH & $43.2 \pm 12.9$ \\
\hline$\left[\mathrm{Ala}^{7}\right] \mathrm{NPFF}$ & F-L-F-Q-P-Q-Ala-F-NH & $2359 \pm 617$ \\
\hline$\left[\mathrm{Tyr}^{8}\right] \mathrm{NPFF}$ & F-L-F-Q-P-Q-R-Tyr-NH & $34.0 \pm 10.2$ \\
\hline$\left[\mathrm{Hph}^{8}\right] \mathrm{NPFF}$ & F-L-F-Q-P-Q-R-Hph-NH & $915 \pm 146$ \\
\hline$\left[\mathrm{Phg}^{8}\right] \mathrm{NPFF}$ & F-L-F-Q-P-Q-R-Phg-NH & $6468 \pm 682$ \\
\hline$\left[\mathrm{Ala}^{8}\right] \mathrm{NPFF}$ & F-L-F-Q-P-Q-R-Ala-NH & $312 \pm 73$ \\
\hline$\left[D-\mathrm{Arg}^{7} ; D-\mathrm{Phe}^{8}\right] \mathrm{NPFF}$ & F-L-F-Q-P-Q-[D-Arg]-[D-Phe]-NH ${ }_{2}$ & $373 \pm 127$ \\
\hline NPFF-OH & F-L-F-Q-P-Q-R-F-OH & $5178 \pm 2195$ \\
\hline
\end{tabular}

${ }^{a}$ Affinity of NPFF-related peptides, inhibiting $\left[{ }^{125} \mathrm{I}\right] 1 \mathrm{DMe}$ specific binding in the dorsal horn of the rat spinal cord. $\mathrm{K}_{\mathrm{i}}$ values are from recent reports $[118,119]$.

As previously reported $[119,120]$, substitutions of the C-terminal Arg and Phe residues result in a significant loss in receptor response. By the use of a systematic approach, we characterized the role of the C-terminal dipeptide with respect to agonistic properties. The synthesized [Xaa ${ }^{7} \mathrm{NPFF}$ and $\left[\mathrm{Xaa}^{8}\right]$ NPFF analogs were used to investigate signal transduction properties in COS-7 cells, transiently expressing human NPFF receptor subtypes [28]. Data are summarized in Table 5.

Substitution of Arg with Ala resulted in a peptide that maintained weak activity, but only at high concentrations $(>1 \mu \mathrm{M})$ for $\mathrm{NPFF}_{1 / 2} \mathrm{R}$. Findeisen et al. [28] were able to further explore the crucial role of $\mathrm{Arg}^{7}$ by modifying this position and show that all alterations resulted in identical behavior at 
the $\mathrm{NPFF}_{1} \mathrm{R}$ and $\mathrm{NPFF}_{2} \mathrm{R}$ : the charge-conserving Lys residue displays the same behavior at both receptors, inducing a $\sim 100$-fold decrease in potency for IP accumulation at NPFFRs. Furthermore, to assess the importance of the cationic guanidinium group within the $\mathrm{Arg}^{7}$ side chain of the NPFF sequence, terminal NH-groups were monomethylated (MMA) or asymmetric dimethylated (ADMA), resulting in analogs that show an equal activity profile at both NPFFRs as well. No significant change in efficacy was observed for either receptor subtype relative to stimulation with parent NPFF. Interestingly, by decreasing the $\mathrm{Arg}^{7}$ side chain by either one or two $\mathrm{CH}_{2}$ groups [replacement by $\alpha$-amino-4-guanidino-butyric acid (Agb) or $\alpha$-amino-3-guanidinopropionic acid (Agp)], the resulting analogs exhibit different activity profiles for both receptors. Low potency was observed for both receptors, but the efficacy was different: the $\left[\mathrm{Agb}^{7}\right] \mathrm{NPFF}$ analog was only able to activate the $\mathrm{NPFF}_{1} \mathrm{R}$ up to $31 \pm 2 \%$ of the wild-type efficacy in contrast to the maximum signal of $96 \pm 13 \%$ observed for $\mathrm{NPFF}_{2} \mathrm{R}$. Other hydrophilic amino acids, such as Asp and Cit resulted in dramatically decreased receptor activation. Findeisen et al. postulated that the length of the side chain is important, and that various molecular dynamics are responsible for formation of the agonist-receptor complex in the $\mathrm{NPFF}_{1} \mathrm{R}$ as compared with the $\mathrm{NPFF}_{2} \mathrm{R}$ [28]. The recently discovered selective $\mathrm{NPFF}_{2} \mathrm{R}$ agonist with a guanidinium group positioned very close to the core structure supports this hypothesis (compounds 1 , 3 and 9; Table 10) [123]. These results are in agreement with the requirement of a long, charged side chain with hydrogen bonding potential at this position, suggesting that the specific role of the Arg is critical for best activation of both NPFF receptors.

Table 4. Binding constants $\left(\mathrm{K}_{\mathrm{i}}\right)$ and functional parameters $\left(\mathrm{EC}_{50}\right)$ of RFamide-related peptides on human NPFF receptors from recent reports [28,120-122].

\begin{tabular}{|c|c|c|c|c|c|c|}
\hline \multirow{2}{*}{ Peptide } & \multirow{2}{*}{ Sequences } & \multicolumn{2}{|c|}{ NPFF1 } & \multicolumn{2}{|c|}{ NPFF2 } & \multirow{2}{*}{ Ref. } \\
\hline & & Binding [nM] & $\mathrm{EC}_{50}[\mathrm{nM}]$ & Binding [nM] & $\mathrm{EC}_{50}[\mathrm{nM}]$ & \\
\hline \multicolumn{7}{|c|}{ Pro-NPFF ${ }_{\mathrm{A}}$-derived peptides } \\
\hline NPFF & FLFQPQRFa & $2.82 \pm 0.06$ & $236 \pm 43 / 12 \pm 6$ & $0.21 \pm 0.03$ & $3 \pm 3$ & {$[28,120]$} \\
\hline NPFF(2-8) & LFQPQRFa & 4.6 & 140 & 3.0 & 8.5 & {$[121]$} \\
\hline NPFF(3-8) & FQPQRFa & 13 & $360 / 26 \pm 5$ & 28 & $25 \pm 3$ & {$[28,121]$} \\
\hline NPFF(4-8) & QPQRFa & 21 & $516 \pm 399$ & 69 & $273 \pm 103$ & {$[28,121]$} \\
\hline NPFF-OH & FLFQPQRF-OH & $>10000$ & & $>1000$ & $>1000$ & {$[120]$} \\
\hline hNPAF & NSQFWSLAAPQRFa & $13.0 \pm 2.0$ & $324 \pm 30$ & $0.14 \pm 0.01$ & $0.53 \pm 0.03$ & [120] \\
\hline \multicolumn{7}{|c|}{ Pro-NPFF ${ }_{\mathrm{B}}$-derived peptides/RFamide related peptides } \\
\hline hRFRP-3 (NPVF) & VPNLPQRFa & $0.59 \pm 0.07$ & $12 \pm 2$ & $23 \pm 2$ & $99 \pm 28$ & {$[28,120]$} \\
\hline hRFRP-3-7 & PNLPQRFa & 0.6 & 3 & 110 & $>1000$ & {$[121]$} \\
\hline hRFRP-3-6 & NLPQRFa & 2.6 & 28 & 230 & $>1000$ & [121] \\
\hline hRFRP-3-5 & LPQRFa & 2.1 & 51 & 76 & $>1000$ & {$[121]$} \\
\hline hRFRP-3-4 & PQRFa & 15 & $1270 \pm 73$ & 26 & $904 \pm 462$ & {$[28,120,121]$} \\
\hline hRFRP-1(NPSF) & MPHSFANLPLRFa & 2.7 & 4.8 & 3.8 & $21 \pm 4 / 330$ & {$[120,121]$} \\
\hline hRFRP-1-5 & LPLRFa & 2.5 & 23 & 16 & $129 \pm 23 / 790$ & {$[120,121]$} \\
\hline PLRFa & PLRFa & $5.4 \pm 0.8$ & $82 \pm 2$ & $0.51 \pm 0.05$ & $6.5 \pm 0.9 / 62 \pm 54$ & {$[28,120,122]$} \\
\hline
\end{tabular}

Data represent mean \pm S.E.M.; $K_{\mathrm{i}}=\mathrm{IC}_{50} /\left[1+L / K_{\mathrm{d}}\right]$ in which $\mathrm{IC}_{50}$ is the concentration of competitor required to displace $50 \%$ of specific binding of the radioligand; $\mathrm{NPFF}_{1}$ receptors were labelled with $\left[{ }^{125} \mathrm{I}\right] \mathrm{YVPNLPQRFa}$ and $\mathrm{NPFF}_{2}$ receptors were labelled with $\left[{ }^{125} \mathrm{I}\right] \mathrm{EYWSLAAPQRFa}$ by Mollereau et al. [120,122]. Yoshida et al. used [ $\left.{ }^{125} \mathrm{I}\right] \mathrm{hRFRP}-3-8$ and [ $\left.{ }^{125} \mathrm{I}\right] \mathrm{NPFF}$ for Binding studies at $\mathrm{NPFF}_{1} \mathrm{R}$ and $\mathrm{NPFF}_{2} \mathrm{R}$, respectively [121]. $\mathrm{EC}_{50}$ is the concentration of agonist that inhibits $50 \%$ of the intracellular cAMP production induced by forskolin [120-122] or that evokes $50 \%$ of full agonist induced signaling in an inositol phosphate accumulation assay [28]. 
To study the critical role of the C-terminal phenylalanine, a series of [Phe $\left.{ }^{8}\right] \mathrm{NPFF}$ analogs with aromatic and aliphatic amino acids, as well as modifications of the Phe side chain, was investigated by comparing the activity profiles (Table 5). The substitution with alanine led to nearly complete loss of receptor activity for both subtypes, which is in agreement with previous binding studies using the dorsal horn of the rat spinal cord [119]. Interestingly, the activity was essentially equipotent at both NPFF receptor subtypes after replacement with a cyclohexyl group at position 8 of NPFF and resulted in an approximate five-fold decreased potency. The presence of a hydroxy group in the Tyr side chain resulted in an agonistic peptide with $\sim 24$-fold loss in potency for both NPFFRs.

Table 5. Comparison of potency $\left(\mathrm{EC}_{50}\right)$ and efficacy $\left(\mathrm{E}_{\max }\right)$ at the human $\mathrm{NPFF}_{1}$ and $\mathrm{NPFF}_{2}$ receptors for NPFF analogs containing modifications in the RFamide motif [28].

\begin{tabular}{|c|c|c|c|c|c|}
\hline \multirow{2}{*}{ Peptide } & \multirow{2}{*}{ Sequence } & \multicolumn{2}{|c|}{$\mathrm{hNPFF}_{1}$ receptor } & \multicolumn{2}{|c|}{$\mathrm{hNPFF}_{2}$ receptor } \\
\hline & & $\mathbf{E C}_{50}[\mathrm{nM}]$ & $\mathbf{E}_{\max }[\%]$ & $\mathbf{E C}_{50}[\mathrm{nM}]$ & $\mathbf{E}_{\max }[\%]$ \\
\hline NPFF & F-L-F-Q-P-Q-R-F-NH ${ }_{2}$ & $12 \pm 6$ & 100 & $3 \pm 3$ & 100 \\
\hline$\left[\mathrm{Ala}^{7}\right] \mathrm{NPFF}$ & F-L-F-Q-P-Q-A-F-NH ${ }_{2}$ & $7610 \pm 1250$ & $26 \pm 4$ & $1228 \pm 296$ & $(60 \pm 9)$ \\
\hline$\left[\mathrm{Cit}^{7}\right] \mathrm{NPFF}$ & F-L-F-Q-P-Q-Cit-F-NH ${ }_{2}$ & $3170 \pm 640$ & $66 \pm 8$ & $2469 \pm 1167$ & $59 \pm 6$ \\
\hline \multicolumn{6}{|c|}{ charged side chains/ missing guanidine group } \\
\hline$\left[\right.$ Lys $\left.^{7}\right] \mathrm{NPFF}$ & F-L-F-Q-P-Q-K-F-NH & $1290 \pm 340$ & $83 \pm 14$ & $565 \pm 21$ & $(81 \pm 9)$ \\
\hline$\left[\mathrm{Orn}^{7}\right] \mathrm{NPFF}$ & F-L-F-Q-P-Q-Orn-F-NH ${ }_{2}$ & $3510 \pm 1000$ & $57 \pm 12$ & $1692 \pm 237$ & $74 \pm 1$ \\
\hline \multicolumn{6}{|c|}{ arginine side chain alterations } \\
\hline$\left[\mathrm{MMA}^{7}\right] \mathrm{NPFF}$ & F-L-F-Q-P-Q-N ${ }^{\omega}$ MeArg-F-NH 2 & $242 \pm 7$ & $109 \pm 2$ & $44 \pm 19$ & $101 \pm 24$ \\
\hline$\left[\mathrm{ADMA}^{7}\right] \mathrm{NPFF}$ & F-L-F-Q-P-Q-N ${ }^{\omega} \mathbf{N}^{\omega} \mathbf{M e A r g - F - \mathrm { NH } _ { 2 }}$ & $1040 \pm 500$ & $75 \pm 4$ & $236 \pm 38$ & $96 \pm 2$ \\
\hline$\left[\mathrm{Agb}^{7}\right] \mathrm{NPFF}$ & F-L-F-Q-P-Q-Agb-F-NH 2 & $1390 \pm 180$ & $31 \pm 2$ & $1219 \pm 1017$ & $96 \pm 13$ \\
\hline$\left[\mathrm{Agp}^{7}\right] \mathrm{NPFF}$ & F-L-F-Q-P-Q-Agp-F-NH ${ }_{2}$ & $3200 \pm 160$ & $17 \pm 2$ & $1524 \pm 211$ & $54 \pm 3$ \\
\hline \multicolumn{6}{|c|}{ aliphatic side chains $\&$ aromatic side chains } \\
\hline$\left[\mathrm{Ala}^{8}\right] \mathrm{NPFF}$ & F-L-F-Q-P-Q-R-A-NH 2 & ND & - & ND & $(25 \pm 4)$ \\
\hline$\left[\mathrm{Nle}^{8}\right] \mathrm{NPFF}$ & F-L-F-Q-P-Q-R-Nle-NH 2 & $659 \pm 73$ & $93 \pm 11$ & $287 \pm 159$ & $(83 \pm 5)$ \\
\hline$\left[\mathrm{Cha}^{8}\right] \mathrm{NPFF}$ & F-L-F-Q-P-Q-R-Cha-NH 2 & $44 \pm 11$ & $91 \pm 25$ & $17 \pm 8$ & $(98 \pm 4)$ \\
\hline$\left[\mathrm{Tyr}^{8}\right] \mathrm{NPFF}$ & F-L-F-Q-P-Q-R-Y-NH 2 & $301 \pm 116$ & $91 \pm 22$ & $70 \pm 34$ & $(83 \pm 1)$ \\
\hline$\left[\operatorname{Trp}^{8}\right] \mathrm{NPFF}$ & F-L-F-Q-P-Q-R-W-NH 2 & $3410 \pm 120$ & $55 \pm 25$ & $205 \pm 112$ & $(99 \pm 8)$ \\
\hline$\left[\mathrm{His}^{8}\right] \mathrm{NPFF}$ & F-L-F-Q-P-Q-R-H-NH ${ }_{2}$ & $2180 \pm 560$ & $29 \pm 3$ & $2750 \pm 949$ & $67 \pm 2$ \\
\hline \multicolumn{6}{|c|}{ phenylalanine side chain alterations } \\
\hline$\left[\mathrm{pMePhe}^{8}\right] \mathrm{NPFF}$ & F-L-F-Q-P-Q-R-pMePhe-NH 2 & $57 \pm 15$ & $83 \pm 3$ & $5 \pm 1$ & $96 \pm 9$ \\
\hline$\left[D-\mathrm{Phe}^{8}\right] \mathrm{NPFF}$ & F-L-F-Q-P-Q-R-f-NH ${ }_{2}$ & $200 \pm 51$ & $84 \pm 9$ & $132 \pm 22$ & $115 \pm 5$ \\
\hline$\left[\mathrm{Hph}^{8}\right] \mathrm{NPFF}$ & F-L-F-Q-P-Q-R-Hph-NH & $1760 \pm 210$ & $61 \pm 10$ & $1331 \pm 249$ & $98 \pm 18$ \\
\hline$\left[\mathrm{Phg}^{8}\right] \mathrm{NPFF}$ & F-L-F-Q-P-Q-R-Phg-NH & $1780 \pm 514$ & $29 \pm 16$ & $1070 \pm 481$ & $98 \pm 4$ \\
\hline
\end{tabular}

$\mathrm{ND}=\mathrm{EC}_{50}$ value was not determinable as no full receptor activation was observed up to concentration tested $(10 \mu \mathrm{M}) . \mathrm{E}_{\max }$ values were obtained from the IP accumulation assay tested at highest concentration tested $(100 \mu \mathrm{M}) . \mathrm{E}_{\max }$ values in parentheses were estimated at $10 \mu \mathrm{M}$. Values are the mean $( \pm \mathrm{SEM})$ and all data values are from our recent report [28].

In contrast, substitution of $\mathrm{Phe}^{8}$ with Trp or His did not generate potent peptides for $\mathrm{NPFF}_{1} \mathrm{R}$. Both peptides exhibit agonistic activity, but their efficacy was drastically reduced. However, the C-terminal $\mathrm{Phe}^{8}$ was able to be replaced by Trp or His with only a minor loss in potency at the $\mathrm{NPFF}_{2} \mathrm{R}$ relative to the $\mathrm{NPFF}_{1} \mathrm{R}$. Still some agonism was observed by the use of methylated Phe analogs. Introduction of the corresponding enantiomer caused a significant loss in potency for both receptor subtypes. 
Elongation of the side chain by replacement with homophenylalanine (Hph) resulted in a peptide that displayed a significant loss in activity at $\mathrm{NPFF}_{1} \mathrm{R}$ (147-fold) and at $\mathrm{NPFF}_{2} \mathrm{R}$ (444-fold). Remarkably, shortening the Phe side chain to a phenylglycine (Phg) resulted in equipotency for both NPFFRs, although the peptide has decreased efficacy at the $\mathrm{NPFF}_{1} \mathrm{R}$. With respect to the overall peptide structure, we observed that configuration of the $\mathrm{Phe}^{8}$ side chain was of similar importance for both subtypes. Additionally, both NPFF receptors were able to be activated by analogs in which the aromatic group is larger than Phe itself ( $\mathrm{pMePhe).} \mathrm{However,} \mathrm{only} \mathrm{NPFF}_{2} \mathrm{R}$ retained the full maximum signal when the aromatic ring linker is $\mathrm{CH}_{2}-\mathrm{CH}_{2}(\mathrm{Hph})$ or absent $(\mathrm{Phg})$, while repositioning of the phenyl group in relation to the peptide backbone was critical for full $\mathrm{NPFF}_{1} \mathrm{R}$ activation. The results propose that the agonist-receptor complexes for $\mathrm{NPFF}_{1} \mathrm{R}$ are more susceptible to structural modifications (Table 5).

\subsection{SAR of RFamide-Related Peptide 26RFa}

Chartrel et al. have isolated a 26 amino acid RFamide peptide from frog brain (hence 26RFa) [14]. Later, an N-terminally extended form of $26 \mathrm{RFa}$, termed 43RFa or QRFP, was identified and purified from rat brain extract [107]. Both peptides, 26RFa and 43RFa have been isolated from the human spinal cord and hypothalamus [7]. The amino acid sequence of the carboxy-terminal heptapeptide of $26 \mathrm{RFa}$ has been fully conserved from fish to mammals [124] and is probably processed in vivo by prohormone convertases. In previous studies it has been demonstrated, that in mammals the amidation of the C-terminus is essential for biological activity of all RFamide-related peptides [119,125]. Previous data showed that the desamidated 26RFa has a 400-fold loss in affinity for GPR103 compared to the amidated analog [18].

Table 6. Potencies $\left(\mathrm{EC}_{50}\right)$ of $26 \mathrm{RFa}$ and truncated analogs.

\begin{tabular}{|c|c|c|}
\hline Compound & Sequence & $\mathbf{E C}_{50}[\mathrm{nM}]$ \\
\hline $\mathrm{h} 43 \mathrm{RFa}$ & $<$ EDEGSEATGFLPAAGEKTSGPLGNLAEELNGYSRKKGGFSFRF-NH $_{2}$ & $7.7 \pm 1.5$ \\
\hline $\mathrm{h} 26 \mathrm{RFa}$ & TSGPLGNLAEELNGYSRKKGGFSFRF-NH ${ }_{2}$ & $10.4 \pm 1.5$ \\
\hline $26 \mathrm{RFa}(10-26)$ & EELNGYSRKKGGFSFRF-NH ${ }_{2}$ & $37.5 \pm 15.2$ \\
\hline $26 \mathrm{RFa}(13-26)$ & NGYSRKKGGFSFRF-NH 2 & $95.3 \pm 40.7$ \\
\hline $26 \mathrm{RFa}(14-26)$ & GYSRKKGGFSFRF-NH ${ }_{2}$ & $185 \pm 52$ \\
\hline $26 \mathrm{RFa}(18-26)$ & KKGGFSFRF-NH ${ }_{2}$ & $233 \pm 51$ \\
\hline $26 \mathrm{RFa}(19-26)$ & KGGFSFRF-NH${ }_{2}$ & $1710 \pm 521$ \\
\hline $26 \mathrm{RFa}(20-26)$ & GGFSFRF-NH $_{2}$ & $739 \pm 149$ \\
\hline $26 \mathrm{RFa}(21-26)$ & GFSFRF-NH $_{2}$ & $\mathrm{NC}$ \\
\hline$\left[\mathrm{Nva}^{23}\right] 26 \mathrm{RFa}(20-26)$ & GGF-Nva-FRF-NH ${ }_{2}$ & $233 \pm 72$ \\
\hline
\end{tabular}

$\mathrm{NC}=$ not calculable; Pyroglutamic acid is shown as $<\mathrm{E} ; \mathrm{EC}_{50}$-values are presented with S.E.M. All data have been taken from Le Marec et al. [126].

By measuring the potency to induce $\left[\mathrm{Ca}^{2+}\right]_{\mathrm{i}}$ mobilization in $\mathrm{G} \alpha_{16}$-hGPR103-transfected CHO cells, structure-activity studies of a series of analogs revealed that the $26 \mathrm{RFa}$ is equally potent as the $\mathrm{N}$-terminally elongated 43RFa, whereas the conserved heptapeptide $26 \mathrm{RFa}(20-26)$ was substantially less potent (75-fold), but as efficacious as h26RFa to increase $\left[\mathrm{Ca}^{2+}\right]_{i}[126]$. Further on, by using an Ala-scan the authors could show that the last three carboxy-terminal residues Phe-Arg-Phe are 
involved in the activation of human GPR103. The conserved heptapeptide can be optimized at position 23 , by replacing a serine with a norvaline residue to gain a slightly more potent analog compared to the 26RFa(20-26) (Table 6). They investigated the contribution of the C-terminal carboxamide to the biological activity by using a series of mono- and disubstituted amide 26RFa(20-26) analogs. With these experiments, they could demonstrate that the C-terminal primary amide is involved in receptor binding via a hydrogen bond [126]. The gradual decline in the biological activity observed with the $\mathrm{N}$-terminally truncated analogs has to be correlated with the affinity of these fragments for GPR103 [18]. Up to now this is the only activity study, which is published so far.

Regarding to the peptide structure, Thuau et al. described the NMR conformation of 26RFa in water and methanol as well as CD spectroscopic studies. Experiments in methanol suggest that the Pro $^{4}-\mathrm{Arg}^{17}$ region of $26 \mathrm{RFa}$ adopts a well-defined $\alpha$-helical structure [127]. Further on, the helix is flanked by two unstructured regions, a three amino acids short N-terminally one $\left(\mathrm{Thr}^{1}-\mathrm{Gly}^{3}\right)$ and a longer segment consisting of the C-terminally conserved moiety (Lys ${ }^{18}-\mathrm{Phe}^{26}$ ). Both, CD- and NMR-studies, reveal a helix with amphiphatic character consisting of a hydrophobic (residues Leu, $\mathrm{Leu}^{8}, \mathrm{Ala}^{9}$ and $\mathrm{Leu}^{12}$ ) and a hydrophilic face (residues Asn ${ }^{7}, \mathrm{Glu}^{10}, \mathrm{Glu}^{11}, \mathrm{Asn}^{13}$ and Arg ${ }^{17}$ ) [127].

\subsection{SAR of PrRP}

SAR for the PrRPR and its equipotent agonistic ligands PrRP20 and PrRP31 are quite clear. Early findings revealed that the analog with the C-terminal acid of PRP31 is inactive $[8,125]$. $\left.{ }^{125} \mathrm{I}\right]-\operatorname{PrRP} 20$ is described as a high affinity ligand, whereas other peptides like NPY, NPFF, RFRP-1 or RFRP-3 show affinities $>30 \mu \mathrm{M}[9,128]$. In a down-sizing attempt, Roland et al. identified the heptapeptide PrRP25-31 to be the minimal active agonist fragment and confirmed the importance of the C-terminal amidation for the biological activity of PrRP. Using an Ala-scan they figured out that the three Arg residues at positions 23, 26 and 30 are of importance [129]. Danho et al. found that Ac-PrRP-(26-31)-hexapeptide was the smallest agonist sequence, and concluded that the critical amino acids were $\mathrm{Arg}^{26}, \mathrm{Pro}^{27}, \mathrm{Val}^{28}, \mathrm{Arg}^{30}$ and $\mathrm{Ph}^{31}$ [130]. The findings of an L-shaped peptide structure with a sloppy N-terminal region and a hydrophobic cluster consisting of $\mathrm{Pro}^{27}$; $\mathrm{Val}^{28}$ and $\mathrm{Phe}^{31}$ were confirmed by recent CD- and NMR-studies revealing an amphiphilic helix of the carboxy-terminal region [130,131]. The first comprehensive study on structure-activity relationships at a plethora of PrRP(19-31) analogs was performed by Boyle et al. [125] (Table 7). The data confirmed the role of the functionally important residues that are located within the carboxy-terminal heptapeptide segment $\mathrm{Ile}^{25}-\mathrm{Arg}^{26}-\mathrm{PrO}^{27}-\mathrm{Val}^{28}-\mathrm{Gly}^{29}-\mathrm{Arg}^{30}-\mathrm{Phe}^{31}-\mathrm{NH}_{2}$, especially of residues $\mathrm{Arg}^{26}, \mathrm{Arg}^{30}, \mathrm{Phe}^{31}$ as well as the C-terminal amide function. Repositioning of the aromatic ring at $\mathrm{Phe}^{31}$ was not tolerated and substitution of aliphatic or polar residues resulted in little functional activity. In contrast, substitutions of the aromatic ring in correct distance to the backbone were well tolerated.

No functional activity was observed for any modification made at position $\mathrm{Arg}^{30}$, emphasizing its crucial role, whereas $\mathrm{Arg}^{26}$ is also relevant but has reduced impact [125]. Gly ${ }^{29}$ is very important for good functional activity and even slight changes are poorly tolerated. Pro ${ }^{27}$ is probably required for its turn-promoting property as modifications resulted in less affinity. $\mathrm{Val}^{28}$ could be replaced by Phg with full retention of functional and binding activity, indicating that it is supplying a reasonably sized hydrophobic side chain in the L-configuration and exhibiting branching close to the peptide backbone. 
$\mathrm{Ile}^{25}$ also accepts substitution by Phg but it seems to be a less important position as Ala in position 25 also retained considerable functional activity. The data obtained from a minor number of analogs in positions 21 to 23 confirm that these residues are less important. Backbone methylation from positions 26 to 31 resulted in reduced or none functional activity [125].

Table 7. Activities for the PrRP-(19-31)-peptide Analogs.

\begin{tabular}{|c|c|c|c|}
\hline PrRP20 analogs & C-terminal sequence and numbering & $\begin{array}{l}\text { Binding } \\
\mathbf{K}_{\mathrm{i}}[\mathbf{n M}]\end{array}$ & $\begin{array}{c}\text { FLIPR } \\
\text { EC }_{50}[\mathrm{nM}]\end{array}$ \\
\hline PrRP19-31/PrRP20 & $\ldots-\mathrm{I}^{25}-\mathrm{R}^{26}-\mathrm{P}^{27}-\mathrm{V}^{28}-\mathrm{G}^{29}-\mathrm{R}^{30}-\mathrm{F}^{31}-\mathrm{NH}_{2}$ & 5.3 & 20 \\
\hline PrRP19-31-NHMe & ...-I-R-P-V-G-R-F-NHMe & 4.4 & $\mathrm{n} / \mathrm{a}$ \\
\hline PrRP19-31-OMe & ...-I-R-P-V-G-R-F-OMe & 35.3 & $\mathrm{n} / \mathrm{a}$ \\
\hline PrRP19-31-OH & ...-I-R-P-V-G-R-F-OH & 5000 & NF \\
\hline$\left[\mathrm{His}(\mathrm{Bzl})^{31}\right] \operatorname{PrRP} 19-31$ & ...-I-R-P-V-G-R-His(Bzl) ${ }^{31}-\mathrm{NH}_{2}$ & 4.7 & 20 \\
\hline$\left[\mathrm{Me}_{\alpha} \mathrm{Phe}^{31}\right] \operatorname{PrRP} 19-31$ & $\ldots-$-I-R-P-V-G-R-Me $\mathbf{C}_{\alpha} \mathbf{P h e}^{31}-\mathrm{NH}_{2}$ & 215 & 4950 \\
\hline$\left[\mathrm{Phg}^{31}\right] \operatorname{PrRP} 19-31$ & ...-I-R-P-V-G-R-Phg ${ }^{31}-\mathrm{NH}_{2}$ & 199 & $\mathrm{n} / \mathrm{a}$ \\
\hline$\left[\mathrm{Hph}^{31}\right] \operatorname{PrRP} 19-31$ & $\ldots-\mathrm{I}-\mathrm{R}-\mathrm{P}-\mathrm{V}-\mathrm{G}-\mathrm{R}-\mathrm{Hph}^{31}-\mathrm{NH}_{2}$ & 517 & $\mathrm{n} / \mathrm{a}$ \\
\hline$\left[D-\right.$ Phe $\left.^{31}\right] \operatorname{PrRP} 19-31$ & ...-I-R-P-V-G-R-D-Phe ${ }^{31}-\mathrm{NH}_{2}$ & 887 & $\mathrm{n} / \mathrm{a}$ \\
\hline$\left[\mathrm{Ala}^{30}\right] \operatorname{PrRP} 19-31$ & ...-I-R-P-V-G-Ala ${ }^{30}-\mathrm{F}-\mathrm{NH}_{2}$ & NF & NF \\
\hline$\left[\mathrm{Lys}^{30}\right] \operatorname{PrRP} 19-31$ & $\ldots-$-I-R-P-V-G-Lys ${ }^{30}-\mathrm{F}-\mathrm{NH}_{2}$ & NF & NF \\
\hline$\left[\mathrm{Ala}^{29}\right] \operatorname{PrRP} 19-31$ & ...-I-R-P-V-Ala ${ }^{29}-\mathrm{R}-\mathrm{F}-\mathrm{NH}_{2}$ & 94.5 & 240 \\
\hline$\left[\mathrm{Me}_{\alpha} \mathrm{Ala}^{29}\right] \operatorname{PrRP} 19-31$ & $\ldots$-I-R-P-V-Me ${ }_{\alpha}$ Ala $^{29}$-R-F-NH 2 & 375 & 2270 \\
\hline$\left[D-\mathrm{Ala}^{29}\right] \operatorname{PrRP} 19-31$ & $\ldots-\mathrm{I}-\mathrm{R}-\mathrm{P}-\mathrm{V}-\boldsymbol{D}-\mathrm{Ala}^{29}$-R-F-NH ${ }_{2}$ & 5000 & $\mathrm{NF}$ \\
\hline$\left[\mathrm{Phg}^{28}\right] \operatorname{PrRP} 19-31$ & ...-I-R-P-Phg ${ }^{28}$-G-R-F-NH & 4.7 & 10 \\
\hline$\left[D-\mathrm{Val}^{28}\right] \operatorname{PrRP} 19-31$ & ...-I-R-P-D-Val ${ }^{28}$-G-R-F-NH ${ }_{2}$ & 2640 & $\mathrm{n} / \mathrm{a}$ \\
\hline$\left[\mathrm{Me}_{\alpha} \mathrm{Ala}^{27}\right] \operatorname{PrRP} 19-31$ & ...-I-R-Me ${ }_{\alpha} \mathbf{A l a}^{27}$-V-G-R-F-NH ${ }_{2}$ & 63 & 130 \\
\hline$\left[\mathrm{Ala}^{27}\right] \operatorname{PrRP} 19-31$ & ...-I-R-Ala ${ }^{27}-\mathrm{V}-\mathrm{G}-\mathrm{R}-\mathrm{F}-\mathrm{NH}_{2}$ & 187 & $\mathrm{n} / \mathrm{a}$ \\
\hline$\left[\mathrm{Lys}^{26}\right] \operatorname{PrRP} 19-31$ & $\ldots-\mathrm{I}-\mathbf{L y s}{ }^{26}-\mathrm{P}-\mathrm{V}-\mathrm{G}-\mathrm{R}-\mathrm{F}-\mathrm{NH}_{2}$ & 22 & 120 \\
\hline$\left[\mathrm{Phg}^{25}\right] \operatorname{PrRP} 19-31$ & $\ldots$-Phg ${ }^{25}-\mathrm{R}-\mathrm{P}-\mathrm{V}-\mathrm{G}-\mathrm{R}-\mathrm{F}-\mathrm{NH}_{2}$ & 8.2 & 10 \\
\hline
\end{tabular}

$\mathrm{NF}=$ non-functional; $\mathrm{n} / \mathrm{a}=$ not available; Eu-(Lys)PrRP31 displacement binding assay of HEK293-ASR1 Cells was performed. All data are from Boyle et al. [125]

Recently, the investigations at position $\mathrm{Phe}^{31}$ have been intensified and confirmed the important function of Phe ${ }^{31}$ PrRP analogs in vivo and in vitro, with respect to binding, activity, and food intake in fastened mice after central administration [132]. In detail, analogs with deleted Phe or containing Phe derivatives with bulky side chain or halogenated aromatic ring were tested and revealed high binding potency and cell signaling in RC-4B/C cells [132].

\subsection{SAR of Kisspeptin/Metastin}

Since the discovery of the kisspeptin receptor (GPR54) and its full-length ligand Kp-54, numerous peptide and non-peptide ligands have been investigated in structure-activity studies. The smallest highly potent agonist represents the N-terminally truncated $\mathrm{Kp}-10$ and was the lead structure for further structure-activity studies (Figure 1) [15,133]. Later studies revealed that an even minor alteration of the amidated C-terminus is not tolerated at all [134]. Initial $D$-amino acid scanning experiments of Kp-10 revealed that the five C-terminal residues are stereochemically of high importance for proper kisspeptin receptor activation [135]. This is in a line with NMR solution 
experiments of a Kp-13 in a membrane-like environment (SDS micelles), suggesting a relatively stable, helical conformation from residues 7 to 13 [136]. Similar results were obtained by molecular modeling, showing that Kp-10 exhibits a helical structure of the C-terminal 7 residues in an $\alpha$ - and $3_{10}$-characteristic [133]. In Ala-scanning experiments of Kp-10, the residues $\mathrm{Phe}^{6}$, $\mathrm{Arg}^{9}$, and $\mathrm{Phe}^{10}$ resulted in a high loss of agonistic activity [133,135,136], which structurally fits well with the structural data, as these three residues lie on one face of the helix and define a pharmacophore site for kisspeptin [136]. Structure-activity studies at the C-terminal Phe resulted in an improved activity by substitution with Trp (Table 8) [136,137].

Figure 1. Sequences and bioactivity of down-sized agonists for the kisspeptin receptor (GPR54). Truncated Kp-10 was used as lead structure for developing FTM080 and FTM145 (Scheme is based on Oishi et al. [138]). EC 50 values represent the concentration required for $50 \%$ of the full agonistic activity induced by $\mathrm{Kp}-10(1 \mu \mathrm{M})$ [139].

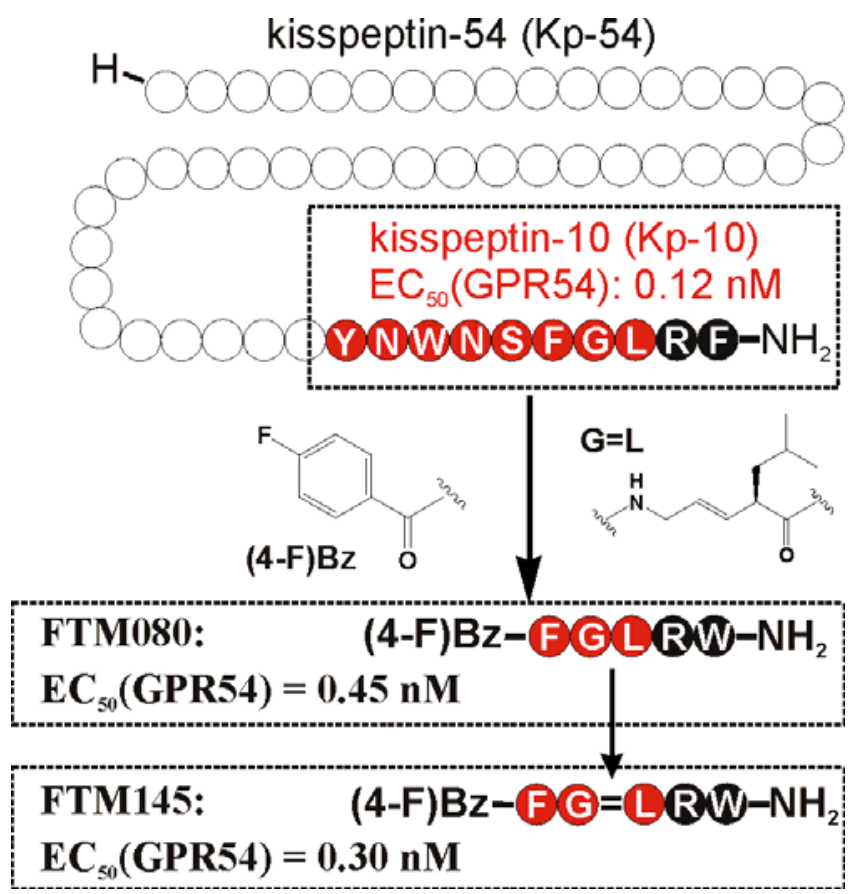

Based on this knowledge, Niida et al. developed the significantly down-sized analogs FM052a and FM053a with Kp-10 like agonistic activity (Table 8) [135]. Extensive optimization of this pentapeptide-based C-terminal kisspeptin analogs resulted in the potent kisspeptin receptor (GPR54) agonist: H-Amb-Nal(2)-Gly-Leu-Arg-Trp- $\mathrm{NH}_{2}$ (compound 34; Table 8) [134]. Further SAR and QSAR studies, performed on the N-terminal acyl groups of the pentapeptide agonists demonstrated that an aromatic acyl group and the inductive electronegative as well as small substituents at 4-position of the aromatic ring contributed to the agonistic activity. This resulted in the identification of the kisspeptin receptor (GPR54) activating agonist FTM080, which is equipotent with Kp-10 (Figure 1) [140]. The analog FTM145 was developed to prevent degradation by proteinases under physiological conditions, in which the $(E)$-alkene dipeptide isostere at the Gly-Leu site was inserted. FTM145 revealed a higher stability in murine serum and resistance to matrix metalloproteinase mediated cleavage as its half-life was increased up to $38 \mathrm{~h}$, whereas Kp-10 was completely digested after 1 hour [139,141]. Kp-10 exhibited highly potent binding affinity and receptor activation at both NPFF receptors, whereas 
FTM145 and FTM080 showed reduced bioactivity toward NPFFRs, yet retaining equipotent bioactivity as Kp-10 toward kisspeptin receptor (GPR54). Highly selective agonists are as important as specific receptor antagonists for functional investigations.

Table 8. Binding parameters $\left(\mathrm{IC}_{50}\right)$ and potencies $\left(\mathrm{EC}_{50}\right)$ of selected kisspeptin analogs.

\begin{tabular}{|c|c|c|c|c|c|}
\hline Compound & Sequence & $\mathbf{E}_{\max }[\%]$ & $\mathrm{IC}_{50}[\mathrm{nM}]$ & $\mathrm{EC}_{50}[\mathrm{nM}]$ & Ref. \\
\hline Kp-10 & Y-N-W-N-S-F-G-L-R-F-NH & $100.3 \pm 7.3^{\mathrm{a}}$ & 0.12 & 0.12 & {$[133,138]$} \\
\hline NF1 & N-R-N-F-L-R-F-NH ${ }_{2}$ & NT & NT & $8000 \pm 700$ & [137] \\
\hline $\operatorname{Trp}^{7}-\mathrm{NF} 1$ & N-R-N-F-L-R-W-NH ${ }_{2}$ & NT & NT & $2100 \pm 300$ & [137] \\
\hline $\mathrm{Gly}^{4}, \mathrm{Trp}^{7}-\mathrm{NF} 1$ & N-R-N-G-L-R-W-NH ${ }_{2}$ & NT & NT & 200 & [137] \\
\hline$[D-Y]^{1} \mathrm{Kp}-10$ & {$[D-\mathrm{Y}]-\mathrm{N}-\mathrm{W}-\mathrm{N}-\mathrm{S}-\mathrm{F}-\mathrm{G}-\mathrm{L}-\mathrm{R}-\mathrm{F}-\mathrm{NH}_{2}$} & NT & $3.6 \pm 0.3$ & NT & [142] \\
\hline FM052a & BisPy-Amb-F-G-L-R-W-NH & $88.9 \pm 2.6^{\mathbf{a}}$ & NT & 3.3 & {$[134,135]$} \\
\hline FM053a & Gu-Amb-F-G-L-R-W-NH ${ }_{2}$ & $93.7 \pm 1.8^{\mathrm{a}}$ & NT & 1.4 & {$[134,135]$} \\
\hline Compound 34 & H-Amb-Nal(2)-G-L-R-W-NH ${ }_{2}$ & $88.9 \pm 0.4^{\mathrm{a}}$ & NT & 0.82 & [134] \\
\hline FTM080 & (4-F)Bz-F-G-L-R-W-NH & NT & 0.71 & $0.45^{b}$ & [140] \\
\hline FTM145 & $(4-F) B z-F-G\left(\psi(1) L-R-W-N_{2}\right.$ & NT & 0.12 & $0.30^{b}$ & [140] \\
\hline
\end{tabular}

Abbreviations: BisPy: bis[(2-pyridinyl)methyl]; Amb: 4-aminomethylbenzoic acid; Gu: guanidine; $\mathrm{Nal}(2)$ : 3-(2-naphthyl)alanine; $\psi$ 1: $(E)-\mathrm{CH}=\mathrm{CH}-;$ (4-F)Bz: 4-fluorobenzoyl; ${ }^{\mathrm{a}} \%$ activity are based on the relative maximum agonistic activity induced by $10 \mathrm{nM}$ of the compounds (\%). Maximum agonistic activity signal at $1 \mu \mathrm{M} \mathrm{Kp}-10$ was used as reference $(100 \%) .{ }^{b} \mathrm{EC}_{50}$ values represent the concentration required for $50 \%$ of the full agonistic activity induced by $\mathrm{Kp}-10(1 \mu \mathrm{M})$. NT $=$ not tested.

It should be noted, that Curtis et al. also tested several $\mathrm{Kp}-10$ analogs and describe $[D-\mathrm{Y}]^{1} \mathrm{Kp}-10$ to bind to kisspeptin receptor (GPR54) with lower affinity while exhibiting similar bioactivity in vitro. However, peripheral administration of $[D-\mathrm{Y}]^{1} \mathrm{Kp}-10$ increased plasma $\mathrm{LH}$ and testosterone in vivo more potently than $\mathrm{Kp}-10$ itself in mice. $[D-\mathrm{Y}]^{1} \mathrm{Kp}-10$ was suggested to be more stable for proteolytic degradation compared to endogenous Kp-10. This hypothesis was supported by significantly increased total testosterone levels, measured $60 \mathrm{~min}$ after injection of $0.15 \mathrm{nmol}[D-\mathrm{Y}]^{1} \mathrm{Kp}-10$ whereas the same dose of Kp-10 had no significant effect.

\section{Crosstalk/Therapeutical Potential}

The RFamide peptides represent a family with a strong therapeutic potential as they are involved in numerous regulatory mechanisms related to energy homeostasis, reproduction, pain and behavioral processes like food intake, locomotion and stress response. Their roles in the regulation of hypothalamic functions are summarized in Figure 2 and reflect the multiple mediated effects but more importantly their different impact on these functions. Due to the structural homology of the RFamide peptides they are susceptible to address other GPCRs within this family and evoke a so called crosstalk. This fact is a hurdle in investigations of the distinct roles for single RFamide peptides, e.g. the Kp-10 was described to target the NPFF receptors with low nanomolar affinities [138] and PrRP effects were found to be mediated through the NPFF receptors as well [76]. But also the NPFF receptors themselves share high affinities to their endogenous ligands, NPFF and RFRP-3 (NPVF) [28] and the $\mathrm{NPFF}_{2} \mathrm{R}$ has even been described to bind the $\mathrm{Y}_{1}$ receptor antagonist BIBP3226. The capability to perform crosstalk is reasonably high for the family of RFamide peptides and thus, selective agonists as well as antagonists are needed to explore the distinct and yet not fully understood mechanism of the 
evoked diverse pharmacological effects. The development of small ligands might finally lead to small, low molecular weight and lipophilic compounds/ligands as drugs/tools to use them in therapy. As all RFamide peptides take part in fundamental neuroendocrine, behavioral and sensory functions the exploration of selective agonists and antagonists is a fundamental step to gain knowledge of distinct interactions.

Figure 2. The family of human RFamide peptides and their respective receptors are presented in a summary of our current understanding of their main roles in the regulation of hypothalamic function. The scheme is based on Ebling et al. [143]. Details have been reported by Bechtold et al. [51] and Osugi et al. [144].

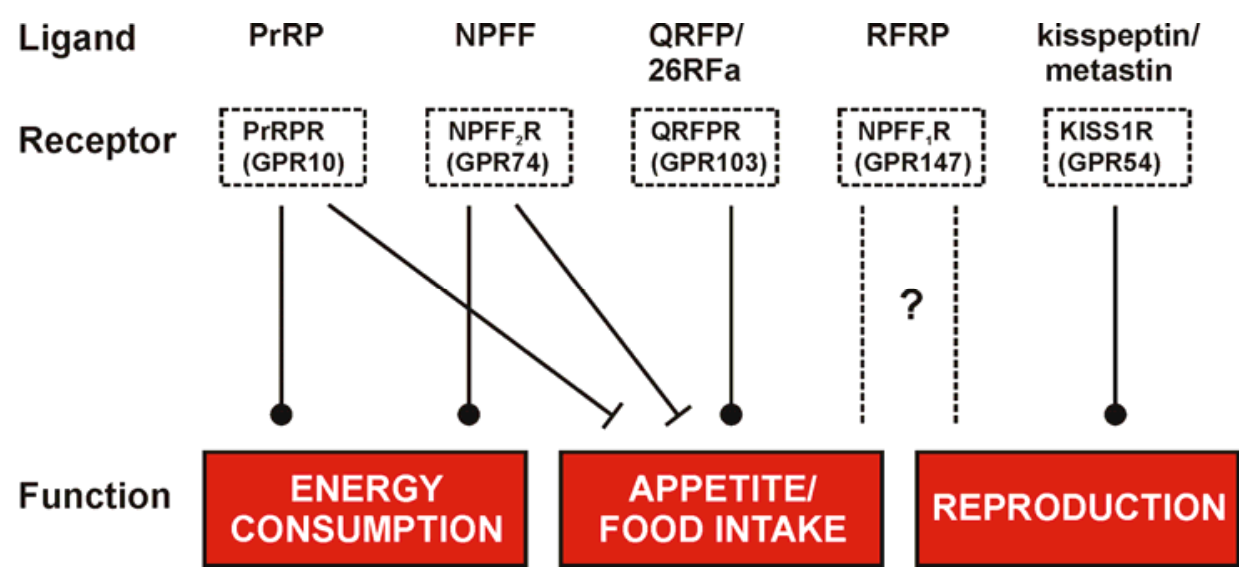

\subsection{Antagonists for the RFamide System}

Antagonists, especially highly selective ones are a tool of choice for the investigation of distinct physiological effects mediated by single receptors and their ligands in vivo. First steps were made in the development of kisspeptin antagonists, which might provide a valuable instrument to elucidate the physiological and pathophysiological role of kisspeptin in the regulation of reproduction and could offer a unique therapeutic agent for treating hormone-dependent disorders of reproduction, including precocious puberty, endometriosis, and metastatic prostate cancer. The most advanced group of antagonistic compounds was developed for the NPFF receptor ligand system, which represents a promising target for drugs with its impact on nociception, food intake and energy expenditure. They may help to optimize the impact of opiates or improve feeding behavior. Up to now, no specific antagonists have been described for the QRFP receptor (GPR103) and the PrRP receptor (GPR10). But it has to be mentioned, that NPY dosed in the micromolar range showed some antagonistic effects for PrRP [145].

\subsection{Development of Antagonists for the NPFFR/GnIH System}

Several putative antagonists have been reported to target NPFF receptors, e.g. compounds derived from endogenous NPFF ligands. Development of antagonists for the NPFFR/GnIH system included N-terminally truncated peptides, like desaminotyrosyl-FLFQRFamide, dansyl-PQRamide and PFR(Tic)amide [42,146-149]. Unfortunately, most of them act as partial agonists with a low affinity and thus limit their use as pharmacological tools. In 2002, Mollereau et al. showed that BIBP3226, a 
prototypical $\mathrm{NPY}_{1} \mathrm{R}$ non-peptidic antagonist [150], displays high affinities for NPFF receptors [120]. Since then, several studies demonstrated the antagonistic properties of BIBP3226 at NPFF receptors in vitro and in vivo (Table 9). Nevertheless, its application is limited due to its simultaneous blockade $\mathrm{NPY}_{1}$ receptors [64,120,151-153]. It has been suggested that BIBP3226 and related compounds may mediate some of their in vivo effects through NPFF receptors rather than through NPY 1 receptors [154,155]. In 2002, similar compounds to BIBP3226 were described in a patent [156]. Recently, a derivative of the dipeptide RFamide (RF9) has been suggested to be a potent and selective antagonist [157]. Selective binding of RF9 to recombinantly expressed receptors in CHO and COS-1 cells was shown $\left(\mathrm{K}_{\mathrm{i}}\right.$-values of $58 \mathrm{nM}$ and $75 \mathrm{nM}$ for $\mathrm{NPFF}_{1} \mathrm{R}$ and $\mathrm{NPFF}_{2} \mathrm{R}$, respectively) (Table 9). RF9 antagonizes the NPFF-/NPVF-induced agonism in functional assays in vitro and i.c.v. and eliminates NPFF-induced pressure and tachycardiac responses. When RF9 was coinjected with NPFF, it was able to act as an antagonist to block delayed and long-lasting heroin-induced hyperalgesia [157]. Further on, recent data demonstrate that RF9 prevents NPFF-induced drops of the body temperature and morphine analgesia in mice [158]. Taken together it is now clear, that NPFF receptors mediate the hypothermia and anti-morphine action of NPFF. Additionally, data revealed a disinhibitory role of NPFF and NPVF in the hypothalamic PVN. The reduction of evoked bicuculline-sensitive inhibitory postsynaptic currents was described, which was blocked by RF9 [159]. However, in an IP accumulation assay, we observed agonistic activity with full efficacy at both NPFF receptors of transiently transfected COS7 cells after stimulation with RF9 (unpublished data). As former studies of RF9 were tested in cAMP-assays or investigated its activity via stimulation of $\left[{ }^{35} \mathrm{~S}\right] \mathrm{GTP} \gamma \mathrm{S}$ binding to $\mathrm{hNPFF}_{2} \mathrm{R}$ membranes, it can be speculated that different signaling pathways of the NPFF receptors are responsible for the observed different effects. Recent reports suggested that the different activation of NPFF receptors could generate the diversity of pharmacological effects in vivo [62,160].

It should be noted that a couple of patents have described small nonpeptidergic ligands for $\mathrm{NPFF}_{1} \mathrm{R}$ and $\mathrm{NPFF}_{2} \mathrm{R}$. In 2003, a patent reported on small templates of quinolino and quinazolino guanidines where different substitutions on the ring system were carried out [161]. In 2004, derivatives of a thiazole guanidine template with different substitutions have been described as $\mathrm{NPFF}_{1} \mathrm{R}$ antagonists, with $\mathrm{IC}_{50}$-values in low $\mathrm{nM}$ range [162]. Unfortunately, functional data for $h \mathrm{hPFF}_{1} \mathrm{R}$ or $\mathrm{hNPFF} \mathrm{R}_{2}$ as well as binding studies on $\mathrm{hNPFF}_{2} \mathrm{R}$ are missing. A later patent refers to the guanine derivatives linked to an aromatic heterocycle to be used as NPFF receptor antagonists [163]. The most recent patent is based on reference [162], describing further potent and specific, low-molecular antagonists of neuropeptide FF1 receptors with non-peptide or non-peptoid structures [164].

Table 9. Structures, sequences and binding affinity of selected specific antagonists for the kisspeptin, $\mathrm{NPFF}_{1}$ and/or $\mathrm{NPFF}_{2}$ receptors.

\begin{tabular}{|c|c|c|c|c|}
\hline \multicolumn{2}{|c|}{ Selected antagonistic ligands } & Target & Binding \\
receptor & Ref. \\
\hline \multirow{2}{*}{ Compound } & Sequence/structure & $\mathrm{K}_{\mathbf{i}}[\mathbf{n M}]$ & $16.4 \pm 2.3^{\text {a }}$ & {$[122]$} \\
\cline { 2 - 5 } & $\mathrm{NPF}_{1}(\mathrm{RFRP}-3)$ & $461 \pm 107^{\mathrm{a}}$ & {$[157]$} \\
\hline
\end{tabular}


Table 9. Cont.

\begin{tabular}{|c|c|c|c|c|}
\hline \multirow{2}{*}{ RF9 } & $\begin{array}{c}\mathrm{HN}_{-} \mathrm{NH}_{2} \\
\mathrm{NH}_{2}\end{array}$ & $\mathrm{NPFF}_{1}(\mathrm{RFRP}-3)$ & $58 \pm 5^{\mathrm{a}}$ & \\
\hline & & $\mathrm{NPFF}_{2}$ & $75 \pm 9^{\text {a }}$ & \\
\hline $\mathrm{p} 210$ & YNWNGFGwRF-NH ${ }_{2}$ & kisspeptin (metastin) & $3 \pm \mathrm{NA}$ & \multirow{2}{*}{$\begin{array}{l}{[165]} \\
{[166]}\end{array}$} \\
\hline p234 & Ac-aNWNGFGwRF-NH ${ }_{2}$ & kisspeptin (metastin) & $7 \pm \mathrm{NA}(77.4 \pm \mathrm{NA})$ & \\
\hline P234-penetratin & RRMKWKKYaNWNGFGwRF- & kisspeptin (metastin) & $73.1 \pm \mathrm{NA}$ & {$[166]$} \\
\hline 91 & & kisspeptin (metastin) & 3.7 & [167] \\
\hline $15 \mathrm{a}$ & & kisspeptin (metastin) & 3.6 & [168] \\
\hline
\end{tabular}

${ }^{a}$ Values are mean \pm SEM from three or more separate experiments performed in duplicate. $K_{\mathrm{i}}$ values were determined by using $\left[{ }^{125} \mathrm{I}\right] \mathrm{Tyr}-\mathrm{NPFF}$ for $\mathrm{hNPFF}_{2} \mathrm{R}$ and $\left[{ }^{125} \mathrm{I}\right] \mathrm{YVP}$ for $\mathrm{hNPFF}_{1} \mathrm{R}$. NA = value not available; Modifications at the endogenous kisspeptin (metastin) sequence are presented in bold letters and lowercase letters represent residues in D-configuration. 91: N-\{4-[3-(B-Alanylamino)phenyl]-3-cyano-6-(4-fluoro-2hydroxyphenyl)pyridin-2-yl\} furan-2-carboxamide hydrochloride; 15a: N-[3-Cyano-6-(4-fluoro-2-hydroxyphenyl)4-(3-piperazin-1-ylphenyl)pyridin-2-yl]furan-2-carboxamide hydrochloride.

\subsection{Kisspeptin/Metastin System}

Roseweir et al. created some potent peptide antagonists for the kisspeptin receptor (GPR54), based on the substitution of Leu ${ }^{8}$ in Kp-10 with $D$-Trp in combination with Ser $^{5}$ substitution by Gly (Table 9) [165]. The selected antagonist peptide 234 (p234) reduced pulsatile GnRH secretion in female pubertal monkeys and was able to inhibit the firing of GnRH neurons in the brain of the mouse. The inhibitory effect of LH release in rats and mice and the blocking of LH rise in postcastrated sheep, rats, and mice indicate that kisspeptin neurons mediate the negative feedback effect of sex steroids on gonadotropin secretion in mammals [165]. Pineda et al. extended and refined the in vitro and in vivo testing of the first kisspeptin antagonist p234 by its continuous infusion, and additionally tagged the leading antagonist compound p234 with an N-terminal penetration sequence (Table 9) [166]. This is predicted to have a higher permeability through the blood-brain barrier and paves the way for new strategy development for systemic antagonism of (or at least part of) the biological actions of endogenous kisspeptins.

More recently, small molecule kisspeptin receptor (GPR54) antagonists with a 2-acylamino-4,6diphenylpyridine scaffold have been reported (Table 9) [167,168]. Kobayashi et al. used a combinatorial chemistry technology to identify a 2-furoyl group to be the most suitable 2-acyl group of all tested 2-acylamino-4,6-diphenylpyridine derivatives, and finally these structure-activity relationship studies led to compound 91 with an $\mathrm{IC}_{50}$ value of $3.7 \mathrm{nM}$ in a kisspeptin receptor (GPR54) binding assay. Moreover, these compounds showed apparent antagonistic activity in a cellular functional assay [167]. The optimized compound 15a exhibited high affinity to human and rat 
kisspeptin receptor (GPR54), apparent antagonistic activity, and high brain exposure. In addition, intravenous administration of $15 \mathrm{a}$ to castrated male rat suppressed the plasma LH level, which indicates the possibility of a small molecule kisspeptin receptor (GPR54) antagonist as a novel drug for sex-hormone dependent diseases [168].

\subsection{Development of Selective NPFF Receptor Agonists}

Gaubert et al. have reported the discovery and characterization of the first nonpeptidic selective $\mathrm{NPFF}_{2} \mathrm{R}$ agonists. They demonstrated that systemic administration of the selective $\mathrm{NPFF}_{2} \mathrm{R}$ agonists (compound 1 and 3; Table 10) were active in various pain models in vivo, whereas administration of a nonselective $\mathrm{NPFF}_{1} \mathrm{R}$ and $\mathrm{NPFF}_{2} \mathrm{R}$ agonist (compound 9; Table 10) increases sensitivity to noxious and non-noxious stimuli [123].

Table 10. Binding affinity and/or potency data of potent selective agonists for the NPFF receptor system compared with the $\mathrm{NPFF}_{2} \mathrm{R}$ selective agonists NPFF/NPAF.

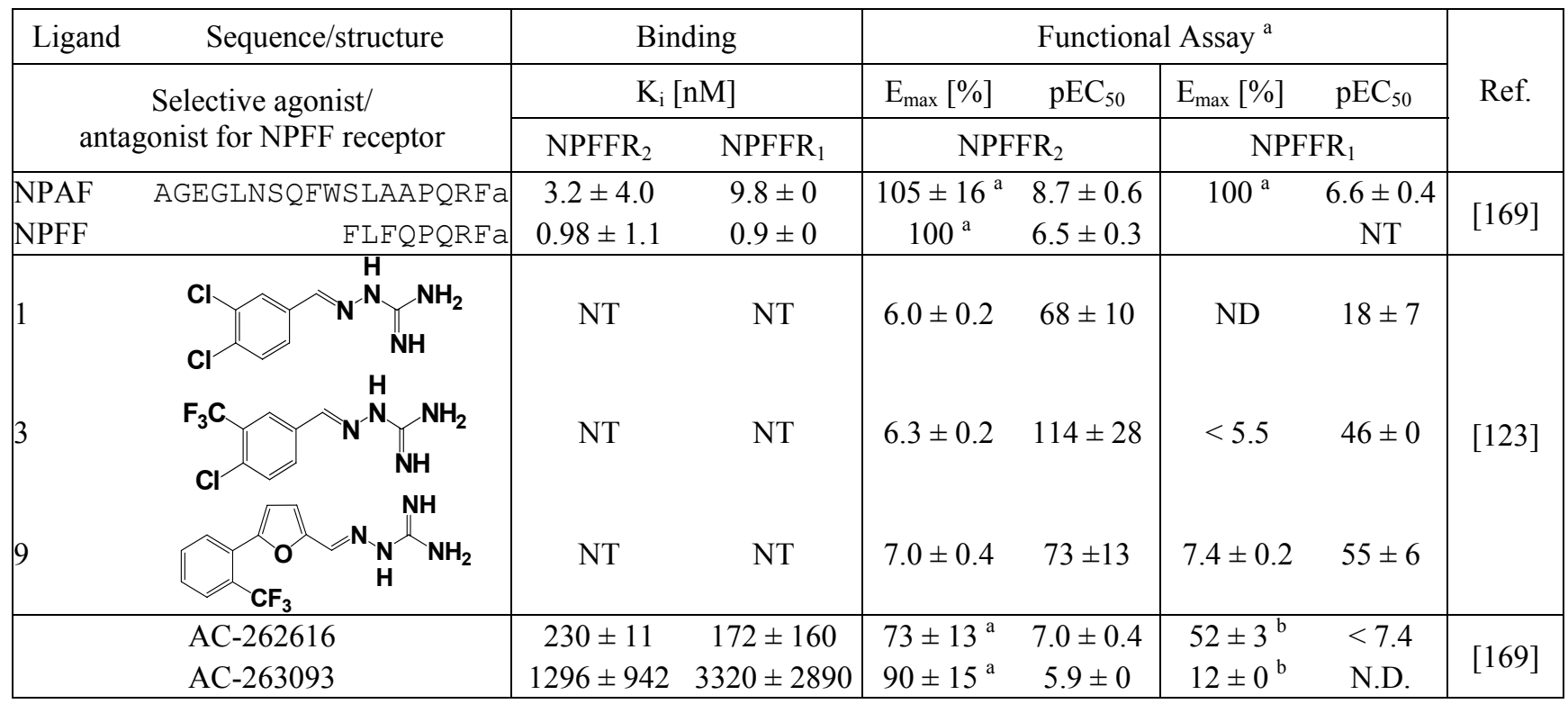

$\mathrm{ND}=$ could not be determined. NT $=$ not tested. ${ }^{a}$ values measured by R-SAT assays. ${ }^{\mathrm{b}} \%$ Eff values reported are those obtained at the highest testable concentration of compound $(6 \mu \mathrm{M})$, due to toxicity of compounds.

By performing two functional assays (R-SAT and cAMP assays) in addition to binding assays using ${ }^{125}$ I-NPFF, Lameh et al. investigated the activity profiles of several novel nonpeptidic, small molecule $\mathrm{NPFF}$ agonists for recombinant human $\mathrm{NPFF}_{1}$ and $\mathrm{NPFF}_{2}$ receptors (Table 10). In this study, they could identify compounds that, according to the performed in vitro functional assays, are selective agonists for $\mathrm{NPFF}_{2} \mathrm{R}$ (i.e., AC-263093) and nonselective agonists (AC-262616) for NPFF receptors (Table 10). Additionally they found AC-262620 and AC-262970 to be selective NPFF ${ }_{1} \mathrm{R}$ antagonists, which bind $\mathrm{NPFF}_{1} \mathrm{R}$ with low nanomolar affinity but behaved as full agonists at $\mathrm{NPFF}_{2} \mathrm{R}$ [169]. Using these compounds they were able to clarify the pharmacology of NPFF receptors after systemic administration. Further on, the in vivo results provide evidence for the divergent roles of NPFF receptor subtypes in the modulation of nociception. They could demonstrate that $\mathrm{NPFF}_{1} \mathrm{R}$ activation is pronociceptive, whereas $\mathrm{NPFF}_{2} \mathrm{R}$ activation is antinociceptive [169]. 


\section{Concluding Remarks}

In recent years, the essential role of RFamide peptides became more and more clear as the number of physiological functions and effects, the peptides participate in, were growing. The regulatory pathways of the RFamide peptides are involved in prominent nodal points like the cardiovascular system, feeding behavior, locomotion, nociception, energy homeostasis reproduction or cancer metastasis. On the one hand, perturbation within these signaling pathways might lead to serious syndromes but on the other hand the RFamide family opens the field to modulate a plethora of undesired effects in a positive manner. This issue is becoming increasingly important, because cancer, eating disorders, failed reproduction or the cardiovascular diseases are problems of our modern society and an ascending role will be their treatment by drugs. To address the correct signaling pathway in a desired manner it is indispensable to further elucidate the role of the distinct RFamide peptides. Therefore, highly selective agonistic and antagonistic compounds/peptides are essential and still needed, as the crosstalks within this family, but also to the NPY system are quite complex and not fully understood. First steps were made for NPFF and kisspeptins, but this path has to be followed further to benefit from the huge modulatory potential of the RFamide peptide system. Herein, we summarize the diverse physiological roles of the RFamide peptide family and provide detailed insight into the latest structure-activity and structure-affinity relationship studies.

\section{Acknowledgments}

Financial support of DFG (SFB 610, BE 1264-11) is kindly acknowledged.

\section{Conflict of Interest}

The authors declare no conflict of interest.

\section{References and Notes}

1. Price, D.A.; Greenberg, M.J. Structure of a molluscan cardioexcitatory neuropeptide. Science 1977, 197, 670-671.

2. Dockray, G.J.; Reeve, J.R., Jr.; Shively, J.; Gayton, R.J.; Barnard, C.S. A novel active pentapeptide from chicken brain identified by antibodies to FMRFamide. Nature 1983, 305, 328-330.

3. Yang, H.Y.; Fratta, W.; Majane, E.A.; Costa, E. Isolation, sequencing, synthesis, and pharmacological characterization of two brain neuropeptides that modulate the action of morphine. Proc. Natl. Acad. Sci. USA 1985, 82, 7757-7761.

4. Panula, P.; Aarnisalo, A.A.; Wasowicz, K. Neuropeptide FF, a mammalian neuropeptide with multiple functions. Prog. Neurobiol. 1996, 48, 461-487.

5. Perry, S.J.; Yi-Kung Huang, E.; Cronk, D.; Bagust, J.; Sharma, R.; Walker, R.J.; Wilson, S.; Burke, J.F. A human gene encoding morphine modulating peptides related to NPFF and FMRFamide. FEBS Lett. 1997, 409, 426-430.

6. Ubuka, T.; Morgan, K.; Pawson, A.J.; Osugi, T.; Chowdhury, V.S.; Minakata, H.; Tsutsui, K.; Millar, R.P.; Bentley, G.E. Identification of human GnIH homologs, RFRP-1 and RFRP-3, and 
the cognate receptor, GPR147 in the human hypothalamic pituitary axis. PLoS One 2009, 4, e8400.

7. Bruzzone, F.; Lectez, B.; Tollemer, H.; Leprince, J.; Dujardin, C.; Rachidi, W.; Chatenet, D.; Baroncini, M.; Beauvillain, J.C.; Vallarino, M.; et al. Anatomical distribution and biochemical characterization of the novel RFamide peptide $26 \mathrm{RFa}$ in the human hypothalamus and spinal cord. J. Neurochem. 2006, 99, 616-627.

8. Hinuma, S.; Habata, Y.; Fujii, R.; Kawamata, Y.; Hosoya, M.; Fukusumi, S.; Kitada, C.; Masuo, Y.; Asano, T.; Matsumoto, H.; et al. A prolactin-releasing peptide in the brain. Nature 1998, 393, 272-276.

9. Langmead, C.J.; Szekeres, P.G.; Chambers, J.K.; Ratcliffe, S.J.; Jones, D.N.; Hirst, W.D.; Price, G.W.; Herdon, H.J. Characterization of the binding of [(125)I]-human prolactin releasing peptide (PrRP) to GPR10, a novel G protein coupled receptor. Br. J. Pharmacol. 2000, 131, 683-688.

10. Kotani, M.; Detheux, M.; Vandenbogaerde, A.; Communi, D.; Vanderwinden, J.M.; Le Poul, E.; Brezillon, S.; Tyldesley, R.; Suarez-Huerta, N.; Vandeput, F.; et al. The metastasis suppressor gene KISS-1 encodes kisspeptins, the natural ligands of the orphan G protein-coupled receptor GPR54. J. Biol. Chem. 2001, 276, 34631-34636.

11. Lee, J.H.; Miele, M.E.; Hicks, D.J.; Phillips, K.K.; Trent, J.M.; Weissman, B.E.; Welch, D.R. KISS-1, a novel human malignant melanoma metastasis-suppressor gene. J. Natl. Cancer Inst. 1996, 88, 1731-1737.

12. Hori, A.; Honda, S.; Asada, M.; Ohtaki, T.; Oda, K.; Watanabe, T.; Shintani, Y.; Yamada, T.; Suenaga, M.; Kitada, C.; et al. Metastin suppresses the motility and growth of CHO cells transfected with its receptor. Biochem. Biophys. Res. Commun. 2001, 286, 958-963.

13. Hinuma, S.; Shintani, Y.; Fukusumi, S.; Iijima, N.; Matsumoto, Y.; Hosoya, M.; Fujii, R.; Watanabe, T.; Kikuchi, K.; Terao, Y.; et al. New neuropeptides containing carboxy-terminal RFamide and their receptor in mammals. Nat. Cell. Biol. 2000, 2, 703-708.

14. Chartrel, N.; Dujardin, C.; Anouar, Y.; Leprince, J.; Decker, A.; Clerens, S.; Do-Rego, J.C.; Vandesande, F.; Llorens-Cortes, C.; Costentin, J.; et al. Identification of 26RFa, a hypothalamic neuropeptide of the RFamide peptide family with orexigenic activity. Proc. Natl. Acad. Sci. USA 2003, 100, 15247-15252.

15. Ohtaki, T.; Shintani, Y.; Honda, S.; Matsumoto, H.; Hori, A.; Kanehashi, K.; Terao, Y.; Kumano, S.; Takatsu, Y.; Masuda, Y.; et al. Metastasis suppressor gene KISS-1 encodes peptide ligand of a G-protein-coupled receptor. Nature 2001, 411, 613-617.

16. Bonini, J.A.; Jones, K.A.; Adham, N.; Forray, C.; Artymyshyn, R.; Durkin, M.M.; Smith, K.E.; Tamm, J.A.; Boteju, L.W.; Lakhlani, P.P.; et al. Identification and characterization of two G protein-coupled receptors for neuropeptide FF. J. Biol. Chem. 2000, 275, 39324-39331.

17. Elshourbagy, N.A.; Ames, R.S.; Fitzgerald, L.R.; Foley, J.J.; Chambers, J.K.; Szekeres, P.G.; Evans, N.A.; Schmidt, D.B.; Buckley, P.T.; Dytko, G.M.; et al. Receptor for the pain modulatory neuropeptides FF and AF is an orphan G protein-coupled receptor. J. Biol. Chem. 2000, 275, 25965-25971. 
18. Fukusumi, S.; Yoshida, H.; Fujii, R.; Maruyama, M.; Komatsu, H.; Habata, Y.; Shintani, Y.; Hinuma, S.; Fujino, M. A new peptidic ligand and its receptor regulating adrenal function in rats. J. Biol. Chem. 2003, 278, 46387-46395.

19. Jiang, Y.; Luo, L.; Gustafson, E.L.; Yadav, D.; Laverty, M.; Murgolo, N.; Vassileva, G.; Zeng, M.; Laz, T.M.; Behan, J.; et al. Identification and characterization of a novel RF-amide peptide ligand for orphan G-protein-coupled receptor SP9155. J. Biol. Chem. 2003, 278, 27652-27657.

20. Muir, A.I.; Chamberlain, L.; Elshourbagy, N.A.; Michalovich, D.; Moore, D.J.; Calamari, A.; Szekeres, P.G.; Sarau, H.M.; Chambers, J.K.; Murdock, P.; et al. AXOR12, a novel human G protein-coupled receptor, activated by the peptide KISS-1. J. Biol. Chem. 2001, 276, 28969-28975.

21. Parker, R.M.; Copeland, N.G.; Eyre, H.J.; Liu, M.; Gilbert, D.J.; Crawford, J.; Couzens, M.; Sutherland, G.R.; Jenkins, N.A.; Herzog, H. Molecular cloning and characterisation of GPR74 a novel G-protein coupled receptor closest related to the Y-receptor family. Brain Res. Mol. Brain Res. 2000, 77, 199-208.

22. Lee, D.K.; Nguyen, T.; O'Neill, G.P.; Cheng, R.; Liu, Y.; Howard, A.D.; Coulombe, N.; Tan, C.P.; Tang-Nguyen, A.T.; George, S.R.; et al. Discovery of a receptor related to the galanin receptors. FEBS Lett. 1999, 446, 103-107.

23. Ballesteros, J.A.; Weinstein, H. Integrated methods for the construction of three-dimensional models and computational probing of structure-function relations in $\mathrm{G}$ protein coupled receptors. Methods Neurosci. 1995, 25, 366-428.

24. Goncharuk, V.; Zeng, Z.; Wang, R.; MacTavish, D.; Jhamandas, J.H. Distribution of the neuropeptide FF1 receptor (hFF1) in the human hypothalamus and surrounding basal forebrain structures: Immunohistochemical study. J. Comp. Neurol. 2004, 474, 487-503.

25. Kersante, F.; Mollereau, C.; Zajac, J.M.; Roumy, M. Anti-opioid activities of NPFF1 receptors in a SH-SY5Y model. Peptides 2006, 27, 980-989.

26. Gouarderes, C.; Mazarguil, H.; Mollereau, C.; Chartrel, N.; Leprince, J.; Vaudry, H.; Zajac, J.M. Functional differences between NPFF1 and NPFF2 receptor coupling: High intrinsic activities of RFamide-related peptides on stimulation of [35S]GTPgammaS binding. Neuropharmacology 2007, 52, 376-386.

27. Merten, N.; Lindner, D.; Rabe, N.; Rompler, H.; Morl, K.; Schoneberg, T.; Beck-Sickinger, A.G. Receptor subtype-specific docking of Asp6.59 with C-terminal arginine residues in Y receptor ligands. J. Biol. Chem. 2007, 282, 7543-7551.

28. Findeisen, M.; Rathmann, D.; Beck-Sickinger, A.G. Structure-activity studies of RFamide peptides reveal subtype-selective activation of neuropeptide FF1 and FF2 receptors. ChemMedChem 2011, 6, 1081-1093.

29. Dupouy, V.; Zajac, J.M. Neuropeptide ff receptors in rat brain: A quantitative light-microscopic autoradiographic study using [125I][D.Tyr1, (NMe)Phe3]NPFF. Synapse 1996, 24, 282-296.

30. Gouarderes, C.; Tafani, J.A.; Mazarguil, H.; Zajac, J.M. Autoradiographic characterization of rat spinal neuropeptide FF receptors by using [125I][D.Tyr1, (NMe)Phe3]NPFF. Brain Res. Bull. 1997, 42, 231-238. 
31. Mollereau, C.; Mazarguil, H.; Zajac, J.M.; Roumy, M. Neuropeptide FF (NPFF) analogs functionally antagonize opioid activities in NPFF receptor-transfected SH-SY5Y neuroblastoma cells. Mol. Pharmacol. 2005, 67, 965-975.

32. Mead, E.J.; Maguire, J.J.; Kuc, R.E.; Davenport, A.P. Kisspeptins are novel potent vasoconstrictors in humans, with a discrete localization of their receptor, $G$ protein-coupled receptor 54, to atherosclerosis-prone vessels. Endocrinology 2007, 148, 140-147.

33. Chu, M.; Xiao, C.; Feng, T.; Fu, Y.; Cao, G.; Fang, L.; di, R.; Tang, Q.; Huang, D.; Ma, Y.; et al. Polymorphisms of KISS-1 and GPR54 genes and their relationships with litter size in sheep. Mol. Biol. Rep. 2011.

34. Nimri, R.; Lebenthal, Y.; Lazar, L.; Chevrier, L.; Phillip, M.; Bar, M.; Hernandez-Mora, E.; de Roux, N.; Gat-Yablonski, G. A novel loss-of-function mutation in GPR54/KISS1R leads to hypogonadotropic hypogonadism in a highly consanguineous family. J. Clin. Endocrinol. Metab. 2011, 96, E536-E545.

35. Welch, S.K.; O'Hara, B.F.; Kilduff, T.S.; Heller, H.C. Sequence and tissue distribution of a candidate G-coupled receptor cloned from rat hypothalamus. Biochem. Biophys. Res. Commun. 1995, 209, 606-613.

36. Fujii, R.; Fukusumi, S.; Hosoya, M.; Kawamata, Y.; Habata, Y.; Hinuma, S.; Sekiguchi, M.; Kitada, C.; Kurokawa, T.; Nishimura, O.; et al. Tissue distribution of prolactin-releasing peptide (PrRP) and its receptor. Regul. Pept. 1999, 83, 1-10.

37. Lin, S.H.; Arai, A.C.; Wang, Z.; Nothacker, H.P.; Civelli, O. The carboxyl terminus of the prolactin-releasing peptide receptor interacts with PDZ domain proteins involved in alpha-amino-3-hydroxy-5-methylisoxazole-4-propionic acid receptor clustering. Mol. Pharmacol. 2001, 60, 916-923.

38. Gouarderes, C.; Sutak, M.; Zajac, J.M.; Jhamandas, K. Antinociceptive effects of intrathecally administered F8Famide and FMRFamide in the rat. Eur. J. Pharmacol. 1993, 237, 73-81.

39. Laguzzi, R.; Nosjean, A.; Mazarguil, H.; Allard, M. Cardiovascular effects induced by the stimulation of neuropeptide FF receptors in the dorsal vagal complex: An autoradiographic and pharmacological study in the rat. Brain Res. 1996, 711, 193-202.

40. Fang, Q.; Li, N.; Jiang, T.N.; Liu, Q.; Li, Y.L.; Wang, R. Pressor and tachycardic responses to intrathecal administration of neuropeptide FF in anesthetized rats. Peptides 2010, 31, 683-688.

41. Allard, M.; Labrouche, S.; Nosjean, A.; Laguzzi, R. Mechanisms underlying the cardiovascular responses to peripheral administration of NPFF in the rat. J. Pharmacol. Exp. Ther. 1995, 274, 577-583.

42. Huang, E.Y.; Li, J.Y.; Tan, P.P.; Wong, C.H.; Chen, J.C. The cardiovascular effects of PFRFamide and PFR(Tic)amide, a possible agonist and antagonist of neuropeptide FF (NPFF). Peptides 2000, 21, 205-210.

43. Jhamandas, J.H.; Harris, K.H.; Petrov, T.; Yang, H.Y.; Jhamandas, K.H. Activation of neuropeptide FF neurons in the brainstem nucleus tractus solitarius following cardiovascular challenge and opiate withdrawal. J. Comp. Neurol. 1998, 402, 210-221.

44. Roth, B.L.; Disimone, J.; Majane, E.A.; Yang, H.Y. Elevation of arterial pressure in rats by two new vertebrate peptides FLFQPQRF-NH2 and AGEGLSSPFWSLAAPQRF-NH2 which are immunoreactive to FMRF-NH2 antiserum. Neuropeptides 1987, 10, 37-42. 
45. Jhamandas, J.H.; MacTavish, D. Central administration of neuropeptide FF causes activation of oxytocin paraventricular hypothalamic neurones that project to the brainstem. $J$. Neuroendocrinol. 2003, 15, 24-32.

46. Murase, T.; Arima, H.; Kondo, K.; Oiso, Y. Neuropeptide FF reduces food intake in rats. Peptides 1996, 17, 353-354.

47. Sunter, D.; Hewson, A.K.; Lynam, S.; Dickson, S.L. Intracerebroventricular injection of neuropeptide FF, an opioid modulating neuropeptide, acutely reduces food intake and stimulates water intake in the rat. Neurosci. Lett. 2001, 313, 145-148.

48. Cline, M.A.; Nandar, W.; Rogers, J.O. Central neuropeptide FF reduces feed consumption and affects hypothalamic chemistry in chicks. Neuropeptides 2007, 41, 433-439.

49. Cline, M.A.; Newmyer, B.A.; Smith, M.L. The anorectic effect of neuropeptide AF is associated with satiety-related hypothalamic nuclei. J. Neuroendocrinol. 2009, 21, 595-601.

50. Cline, M.A.; Godlove, D.C.; Nandar, W.; Bowden, C.N.; Prall, B.C. Anorexigenic effects of central neuropeptide $\mathrm{S}$ involve the hypothalamus in chicks (Gallus gallus). Comp. Biochem. Physiol. A Mol. Integr. Physiol. 2007, 148, 657-663.

51. Bechtold, D.A.; Luckman, S.M. The role of RFamide peptides in feeding. J. Endocrinol. 2007, 192, 3-15.

52. Dockray, G.J. The expanding family of -RFamide peptides and their effects on feeding behaviour. Exp. Physiol. 2004, 89, 229-235.

53. Majane, E.A.; Yang, H.Y. Mammalian FMRF-NH2-like peptide in rat pituitary: Decrease by osmotic stimulus. Peptides 1991, 12, 1303-1308.

54. Sunter, D.; Hewson, A.K.; Lynam, S.; Dickson, S.L. Intracerebroventricular injection of neuropeptide FF, an opioid modulating neuropeptide, acutely reduces food intake and stimulates water intake in the rat. Neurosci. Lett. 2001, 313, 145-148.

55. Herrera-Herrera, M.L.; Salazar-Olivo, L.A. RFamide neuropeptides inhibit murine and human adipose differentiation. Biochem. Biophys. Res. Commun. 2008, 377, $29-34$.

56. Kersante, F.; Wang, J.Y.; Chen, J.C.; Mollereau, C.; Zajac, J.M. Anti-opioid effects of neuropeptide FF receptors in the ventral tegmental area. Neurosci. Lett. 2011, 488, 305-309.

57. Wu, C.H.; Tao, P.L.; Huang, E.Y. Distribution of neuropeptide FF (NPFF) receptors in correlation with morphine-induced reward in the rat brain. Peptides 2010, 31, 1374-1382.

58. Mouledous, L.; Frances, B.; Zajac, J.M. Modulation of basal and morphine-induced neuronal activity by a NPFF(2) selective agonist measured by c-Fos mapping of the mouse brain. Synapse 2010, 64, 672-681.

59. Betourne, A.; Marty, V.; Ceccom, J.; Halley, H.; Lassalle, J.M.; Zajac, J.M.; Frances, B.; Mouledous, L. Central locomotor and cognitive effects of a NPFF receptor agonist in mouse. Peptides 2010, 31, 221-226.

60. Desprat, C.; Zajac, J.M. Hypothermic effects of neuropeptide FF analogues in mice. Pharmacol. Biochem. Behav. 1997, 58, 559-563.

61. Frances, B.; Lahlou, H.; Zajac; J.M. Cholera and pertussis toxins inhibit differently hypothermic and anti-opioid effects of neuropeptide FF. Regul. Pept. 2001, 98, 13-18.

62. Quelven, I.; Roussin, A.; Zajac, J.M. Comparison of pharmacological activities of neuropeptide FF1 and neuropeptide FF2 receptor agonists. Eur. J. Pharmacol. 2005, 508, 107-114. 
63. Mouledous, L.; Barthas, F.; Zajac, J.M. Opposite control of body temperature by NPFF1 and NPFF2 receptors in mice. Neuropeptides 2010, 44, 453-456.

64. Fang, Q.; Guo, J.; He, F.; Peng, Y.L.; Chang, M.; Wang, R. In vivo inhibition of neuropeptide FF agonism by BIBP3226, an NPY Y1 receptor antagonist. Peptides 2006, 27, 2207-2213.

65. Raffa, R.B.; Kim, A.; Rice, K.C.; de Costa, B.R.; Codd, E.E.; Rothman, R.B. Low affinity of FMRFamide and four FaRPs (FMRFamide-related peptides), including the mammalian-derived FaRPs F-8-Famide (NPFF) and A-18-Famide, for opioid mu, delta, kappa 1, kappa 2a, or kappa 2 b receptors. Peptides 1994, 15, 401-404.

66. Gouarderes, C.; Tafani, J.A.; Zajac, J.M. Affinity of neuropeptide FF analogs to opioid receptors in the rat spinal cord. Peptides 1998, 19, 727-730.

67. Malin, D.H.; Lake, J.R.; Hammond, M.V.; Fowler, D.E.; Rogillio, R.B.; Brown, S.L.; Sims, J.L.; Leecraft, B.M.; Yang, H.Y. FMRF-NH2-like mammalian octapeptide: Possible role in opiate dependence and abstinence. Peptides 1990, 11, 969-972.

68. Lake, J.R.; Hammond, M.V.; Shaddox, R.C.; Hunsicker, L.M.; Yang, H.Y.; Malin, D.H. IgG from neuropeptide FF antiserum reverses morphine tolerance in the rat. Neurosci. Lett. 1991, 132, 29-32.

69. Oberling, P.; Stinus, L.; Le Moal, M.; Simonnet, G. Biphasic effect on nociception and antiopiate activity of the neuropeptide FF (FLFQPQRFamide) in the rat. Peptides 1993, 14, 919-924.

70. Vergoni, A.V.; Watanobe, H.; Guidetti, G.; Savino, G.; Bertolini, A.; Schioth, H.B. Effect of repeated administration of prolactin releasing peptide on feeding behavior in rats. Brain Res. 2002, 955, 207-213.

71. Gu, W.; Geddes, B.J.; Zhang, C.; Foley, K.P.; Stricker-Krongrad, A. The prolactin-releasing peptide receptor (GPR10) regulates body weight homeostasis in mice. J. Mol. Neurosci. 2004, 22, 93-103.

72. Seal, L.J.; Small, C.J.; Dhillo, W.S.; Kennedy, A.R.; Ghatei, M.A.; Bloom, S.R. Prolactin-releasing peptide releases corticotropin-releasing hormone and increases plasma adrenocorticotropin via the paraventricular nucleus of the hypothalamus. Neuroendocrinology 2002, 76, 70-78.

73. Maruyama, M.; Matsumoto, H.; Fujiwara, K.; Noguchi, J.; Kitada, C.; Fujino, M.; Inoue, K. Prolactin-releasing peptide as a novel stress mediator in the central nervous system. Endocrinology 2001, 142, 2032-2038.

74. Lin, S.H.S.; Leslie, F.M.; Civelli, O. Neurochemical properties of the prolactin releasing peptide (PrRP) receptor expressing neurons: Evidence for a role of PrRP as a regulator of stress and nociception. Brain Res. 2002, 952, 15-30.

75. Samson, W.K.; Resch, Z.T.; Murphy, T.C. A novel action of the newly described prolactin-releasing peptides: Cardiovascular regulation. Brain Res. 2000, 858, 19-25.

76. Ma, L.; MacTavish, D.; Simonin, F.; Bourguignon, J.J.; Watanabe, T.; Jhamandas, J.H. Prolactin-releasing peptide effects in the rat brain are mediated through the neuropeptide FF receptor. Eur. J. Neurosci. 2009, 30, 1585-1593.

77. Matsumoto, H.; Maruyama, M.; Noguchi, J.; Horikoshi, Y.; Fujiwara, K.; Kitada, C.; Hinuma, S.; Onda, H.; Nishimura, O.; Inoue, K.; et al. Stimulation of corticotropin-releasing 
hormone-mediated adrenocorticotropin secretion by central administration of prolactin-releasing peptide in rats. Neurosci. Lett. 2000, 285, 234-238.

78. Yamada, T.; Mochiduki, A.; Sugimoto, Y.; Suzuki, Y.; Itoi, K.; Inoue, K. Prolactin-releasing peptide regulates the cardiovascular system via corticotrophin-releasing hormone. $J$. Neuroendocrinol. 2009, 21, 586-593.

79. Lawrence, C.B.; Liu, Y.L.; Stock, M.J.; Luckman, S.M. Anorectic actions of prolactin-releasing peptide are mediated by corticotropin-releasing hormone receptors. Am. J. Physiol. Regul. Integr. Comp. Physiol. 2004, 286, R101-R107.

80. Harms, J.F.; Welch, D.R.; Miele, M.E. KISS1 metastasis suppression and emergent pathways. Clin. Exp. Metastasis 2003, 20, 11-18.

81. Gottsch, M.L.; Cunningham, M.J.; Smith, J.T.; Popa, S.M.; Acohido, B.V.; Crowley, W.F.; Seminara, S.; Clifton, D.K.; Steiner, R.A. A role for kisspeptins in the regulation of gonadotropin secretion in the mouse. Endocrinology 2004, 145, 4073-4077.

82. Thompson, E.L.; Patterson, M.; Murphy, K.G.; Smith, K.L.; Dhillo, W.S.; Todd, J.F.; Ghatei, M.A.; Bloom, S.R. Central and peripheral administration of kisspeptin-10 stimulates the hypothalamic-pituitary-gonadal axis. J. Neuroendocrinol. 2004, 16, 850-858.

83. Messager, S.; Chatzidaki, E.E.; Ma, D.; Hendrick, A.G.; Zahn, D.; Dixon, J.; Thresher, R.R.; Malinge, I.; Lomet, D.; Carlton, M.B.; et al. Kisspeptin directly stimulates gonadotropin-releasing hormone release via G protein-coupled receptor 54. Proc. Natl. Acad. Sci. USA 2005, 102, 1761-1766.

84. Navarro, V.M.; Castellano, J.M.; Fernandez-Fernandez, R.; Tovar, S.; Roa, J.; Mayen, A.; Nogueiras, R.; Vazquez, M.J.; Barreiro, M.L.; Magni, P.; et al. Characterization of the potent luteinizing hormone-releasing activity of KISS-1 peptide, the natural ligand of GPR54. Endocrinology 2005, 146, 156-163.

85. de Roux, N.; Genin, E.; Carel, J.C.; Matsuda, F.; Chaussain, J.L.; Milgrom, E. Hypogonadotropic hypogonadism due to loss of function of the KISS1-derived peptide receptor GPR54. Proc. Natl. Acad. Sci. USA 2003, 100, 10972-10976.

86. Seminara, S.B.; Messager, S.; Chatzidaki, E.E.; Thresher, R.R.; Acierno, J.S., Jr.; Shagoury, J.K.; Bo-Abbas, Y.; Kuohung, W.; Schwinof, K.M.; Hendrick, A.G.; et al. The GPR54 gene as a regulator of puberty. N. Engl. J. Med. 2003, 349, 1614-1627.

87. Semple, R.K.; Achermann, J.C.; Ellery, J.; Farooqi, I.S.; Karet, F.E.; Stanhope, R.G.; O'Rahilly, S.; Aparicio, S.A. Two novel missense mutations in G protein-coupled receptor 54 in a patient with hypogonadotropic hypogonadism. J. Clin. Endocrinol. Metab. 2005, 90, 1849-1855.

88. Castellano, J.M.; Navarro, V.M.; Fernandez-Fernandez, R.; Nogueiras, R.; Tovar, S.; Roa, J.; Vazquez, M.J.; Vigo, E.; Casanueva, F.F.; Aguilar, E.; et al. Changes in hypothalamic KISS-1 system and restoration of pubertal activation of the reproductive axis by kisspeptin in undernutrition. Endocrinology 2005, 146, 3917-3925.

89. Stengel, A.; Wang, L.; Goebel-Stengel, M.; Tache, Y. Centrally injected kisspeptin reduces food intake by increasing meal intervals in mice. Neuroreport 2011, 22, 253-257.

90. Quennell, J.H.; Howell, C.S.; Roa, J.A.; Augustine, R.A.; Grattan, D.R.; Anderson, G.M. Leptin deficiency and diet-induced obesity reduce hypothalamic kisspeptin expression in mice. Endocrinology 2011, 152, 1541-1550. 
91. Tena-Sempere, M.; Roa, J.; Aguilar, E.; Dieguez, C.; Pinilla, L. New frontiers in kisspeptin/GPR54 physiology as fundamental gatekeepers of reproductive function. Front. Neuroendocrinol. 2008, 29, 48-69.

92. Popa, S.M.; Clifton, D.K.; Steiner, R.A. The role of kisspeptins and GPR54 in the neuroendocrine regulation of reproduction. Annu. Rev. Physiol. 2008, 70, 213-238.

93. Mead, E.J.; Maguire, J.J.; Kuc, R.E.; Davenport, A.P. Kisspeptins: A multifunctional peptide system with a role in reproduction, cancer and the cardiovascular system. Br. J. Pharmacol. 2007, 151, 1143-1153.

94. Roseweir, A.K.; Millar, R.P. The role of kisspeptin in the control of gonadotrophin secretion. Hum. Reprod. Update 2009, 15, 203-212.

95. Kirby, H.R.; Maguire, J.J.; Colledge, W.H.; Davenport, A.P. International union of basic and clinical pharmacology. LXXVII. Kisspeptin receptor nomenclature, distribution, and function. Pharmacol. Rev. 2010, 62, 565-578.

96. Satake, H.; Hisada, M.; Kawada, T.; Minakata, H.; Ukena, K.; Tsutsui, K. Characterization of a cDNA encoding a novel avian hypothalamic neuropeptide exerting an inhibitory effect on gonadotropin release. Biochem. J. 2001, 354, 379-385.

97. Ducret, E.; Anderson, G.M.; Herbison, A.E. RFamide-related peptide-3, a mammalian gonadotropin-inhibitory hormone ortholog, regulates gonadotropin-releasing hormone neuron firing in the mouse. Endocrinology 2009, 150, 2799-2804.

98. Murakami, M.; Matsuzaki, T.; Iwasa, T.; Yasui, T.; Irahara, M.; Osugi, T.; Tsutsui, K. Hypophysiotropic role of RFamide-related peptide- 3 in the inhibition of LH secretion in female rats. J. Endocrinol. 2008, 199, 105-112.

99. Clarke, I.J.; Sari, I.P.; Qi, Y.; Smith, J.T.; Parkington, H.C.; Ubuka, T.; Iqbal, J.; Li, Q.; Tilbrook, A.; Morgan, K.; et al. Potent action of RFamide-related peptide-3 on pituitary gonadotropes indicative of a hypophysiotropic role in the negative regulation of gonadotropin secretion. Endocrinology 2008, 149, 5811-5821.

100. Johnson, M.A.; Tsutsui, K.; Fraley, G.S. Rat RFamide-related peptide-3 stimulates GH secretion, inhibits LH secretion, and has variable effects on sex behavior in the adult male rat. Horm. Behav. 2007, 51, 171-180.

101. Qi, Y.; Oldfield, B.J.; Clarke, I.J. Projections of RFamide-related peptide-3 neurones in the ovine hypothalamus, with special reference to regions regulating energy balance and reproduction. $J$. Neuroendocrinol. 2009, 21, 690-697.

102. Liu, Q.; Guan, X.M.; Martin, W.J.; McDonald, T.P.; Clements, M.K.; Jiang, Q.; Zeng, Z.; Jacobson, M.; Williams, D.L., Jr.; Yu, H.; et al. Identification and characterization of novel mammalian neuropeptide FF-like peptides that attenuate morphine-induced antinociception. $J$. Biol. Chem. 2001, 276, 36961-36969.

103. Roumy, M.; Garnier, M.; Zajac, J.M. Neuropeptide FF receptors 1 and 2 exert an anti-opioid activity in acutely dissociated rat dorsal raphe and periventricular hypothalamic neurones. Neurosci. Lett. 2003, 348, 159-162.

104. Cline, M.A.; Bowden, C.N.; Calchary, W.A.; Layne, J.E. Short-term anorexigenic effects of central neuropeptide VF are associated with hypothalamic changes in chicks. $J$. Neuroendocrinol. 2008, 20, 971-977. 
105. Cline, M.A.; Sliwa, L.N. Neuropeptide VF-associated satiety involves mu and kappa but not delta subtypes of opioid receptors in chicks. Neurosci. Lett. 2009, 455, 195-198.

106. Fang, Q.; Liu, Q.; Li, N.; Jiang, T.N.; Li, Y.L.; Yan, X.; Wang, R. Cardiovascular effects of intravenous administered 26RFa, a novel RFamide peptide ligand for GPR103, in anaesthetised rats. Eur. J. Pharmacol. 2009, 621, 61-66.

107. Takayasu, S.; Sakurai, T.; Iwasaki, S.; Teranishi, H.; Yamanaka, A.; Williams, S.C.; Iguchi, H.; Kawasawa, Y.I.; Ikeda, Y.; Sakakibara, I.; et al. A neuropeptide ligand of the G protein-coupled receptor GPR103 regulates feeding, behavioral arousal, and blood pressure in mice. Proc. Natl. Acad. Sci. USA 2006, 103, 7438-7443.

108. Moriya, R.; Sano, H.; Umeda, T.; Ito, M.; Takahashi, Y.; Matsuda, M.; Ishihara, A.; Kanatani, A.; Iwaasa, H. RFamide peptide QRFP43 causes obesity with hyperphagia and reduced thermogenesis in mice. Endocrinology 2006, 147, 2916-2922.

109. do Rego, J.C.; Leprince, J.; Chartrel, N.; Vaudry, H.; Costentin, J. Behavioral effects of 26RFamide and related peptides. Peptides 2006, 27, 2715-2721.

110. Primeaux, S.D.; Blackmon, C.; Barnes, M.J.; Braymer, H.D.; Bray, G.A. Central administration of the RFamide peptides, QRFP-26 and QRFP-43, increases high fat food intake in rats. Peptides 2008, 29, 1994-2000.

111. Navarro, V.M.; Fernandez-Fernandez, R.; Nogueiras, R.; Vigo, E.; Tovar, S.; Chartrel, N.; Le Marec, O.; Leprince, J.; Aguilar, E.; Pinilla, L.; et al. Novel role of 26RFa, a hypothalamic RFamide orexigenic peptide, as putative regulator of the gonadotropic axis. J. Physiol. 2006, 573, 237-249.

112. Patel, S.R.; Murphy, K.G.; Thompson, E.L.; Patterson, M.; Curtis, A.E.; Ghatei, M.A.; Bloom, S.R. Pyroglutamylated RFamide peptide 43 stimulates the hypothalamic-pituitary-gonadal axis via gonadotropin-releasing hormone in rats. Endocrinology 2008, 149, 4747-4754.

113. Yamamoto, T.; Miyazaki, R.; Yamada, T. Intracerebroventricular administration of 26RFa produces an analgesic effect in the rat formalin test. Peptides 2009, 30, 1683-1688.

114. Yamamoto, T.; Miyazaki, R.; Yamada, T.; Shinozaki, T. Anti-allodynic effects of intrathecally and intracerebroventricularly administered 26RFa, an intrinsic agonist for GPR103, in the rat partial sciatic nerve ligation model. Peptides 2011, 32, 1262-1269.

115. Baribault, H.; Danao, J.; Gupte, J.; Yang, L.; Sun, B.; Richards, W.; Tian, H. The G-protein-coupled receptor GPR103 regulates bone formation. Mol. Cell. Biol. 2006, 26, 709-717.

116. Zhang, Q.; Qiu, P.; Arreaza, M.G.; Simon, J.S.; Golovko, A.; Laverty, M.; Vassileva, G.; Gustafson, E.L.; Rojas-Triana, A.; Bober, L.A.; et al. P518/Qrfp sequence polymorphisms in SAMP6 osteopenic mouse. Genomics 2007, 90, 629-635.

117. Flohr, S.; Kurz, M.; Kostenis, E.; Brkovich, A.; Fournier, A.; Klabunde, T. Identification of nonpeptidic urotensin II receptor antagonists by virtual screening based on a pharmacophore model derived from structure-activity relationships and nuclear magnetic resonance studies on urotensin II. J. Med. Chem. 2002, 45, 1799-1805.

118. Gicquel, S.; Mazarguil, H.; Desprat, C.; Allard, M.; Devillers, J.P.; Simonnet, G.; Zajac, J.M. Structure-activity study of neuropeptide FF: Contribution of N-terminal regions to affinity and activity. J. Med. Chem. 1994, 37, 3477-3481. 
119. Mazarguil, H.; Gouarderes, C.; Tafani, J.A.; Marcus, D.; Kotani, M.; Mollereau, C.; Roumy, M.; Zajac, J.M. Structure-activity relationships of neuropeptide FF: Role of C-terminal regions. Peptides 2001, 22, 1471-1478.

120. Mollereau, C.; Mazarguil, H.; Marcus, D.; Quelven, I.; Kotani, M.; Lannoy, V.; Dumont, Y.; Quirion, R.; Detheux, M.; Parmentier, M.; et al. Pharmacological characterization of human NPFF(1) and NPFF(2) receptors expressed in CHO cells by using NPY Y(1) receptor antagonists. Eur. J. Pharmacol. 2002, 451, 245-256.

121. Yoshida, H.; Habata, Y.; Hosoya, M.; Kawamata, Y.; Kitada, C.; Hinuma, S. Molecular properties of endogenous RFamide-related peptide-3 and its interaction with receptors. Biochim. Biophys. Acta 2003, 1593, 151-157.

122. Gouarderes, C.; Quelven, I.; Mollereau, C.; Mazarguil, H.; Rice, S.Q.; Zajac, J.M. Quantitative autoradiographic distribution of NPFF1 neuropeptide FF receptor in the rat brain and comparison with NPFF2 receptor by using [125I]YVP and [(125I]EYF as selective radioligands. Neuroscience 2002, 115, 349-361.

123. Gaubert, G.; Bertozzi, F.; Kelly, N.M.; Pawlas, J.; Scully, A.L.; Nash, N.R.; Gardell, L.R.; Lameh, J.; Olsson, R. Discovery of selective nonpeptidergic neuropeptide FF2 receptor agonists. J. Med. Chem. 2009, 52, 6511-6514.

124. Ukena, K.; Vaudry, H.; Leprince, J.; Tsutsui, K. Molecular evolution and functional characterization of the orexigenic peptide $26 \mathrm{RFa}$ and its receptor in vertebrates. Cell Tissue Res. 2011, 343, 475-481.

125. Boyle, R.G.; Downham, R.; Ganguly, T.; Humphries, J.; Smith, J.; Travers, S. Structure-activity studies on prolactin-releasing peptide (PrRP). Analogues of PrRP-(19-31)-peptide. J. Pept. Sci. 2005, 11, 161-165.

126. Le Marec, O.; Neveu, C.; Lefranc, B.; Dubessy, C.; Boutin, J.A.; Do-Rego, J.C.; Costentin, J.; Tonon, M.C.; Tena-Sempere, M.; Vaudry, H.; et al. Structure-activity relationships of a series of analogues of the RFamide-related peptide 26RFa. J. Med. Chem. 2011, 54, 4806-4814.

127. Thuau, R.; Guilhaudis, L.; Segalas-Milazzo, I.; Chartrel, N.; Oulyadi, H.; Boivin, S.; Fournier, A.; Leprince, J.; Davoust, D.; Vaudry, H. Structural studies on 26RFa, a novel human RFamide-related peptide with orexigenic activity. Peptides 2005, 26, 779-789.

128. Engstrom, M.; Brandt, A.; Wurster, S.; Savola, J.M.; Panula, P. Prolactin releasing peptide has high affinity and efficacy at neuropeptide FF2 receptors. J. Pharmacol. Exp. Ther. 2003, 305, 825-832.

129. Roland, B.L.; Sutton, S.W.; Wilson, S.J.; Luo, L.; Pyati, J.; Huvar, R.; Erlander, M.G.; Lovenberg, T.W. Anatomical distribution of prolactin-releasing peptide and its receptor suggests additional functions in the central nervous system and periphery. Endocrinology 1999, 140, 5736-5745.

130. Danho, W.; Swistok, J.; Khan, W.; Truitt, T.; Kurylko, G.; Fry, D.; Greeley, D.; Sun, H.; Dvorozniak, M.; Machie, G.; et al. Structure-activity relationships and bioactive conformations of prolactine releasing peptides. Ligands for a potential obesity target. In Proceedings of the 18th American Peptide Symposium, Boston, MA, USA, July 2003; pp. 750-751. 
131. D'Ursi, A.M.; Albrizio, S.; di Fenza, A.; Crescenzi, O.; Carotenuto, A.; Picone, D.; Novellino, E.; Rovero, P. Structural studies on Hgr3 orphan receptor ligand prolactin-releasing peptide. J. Med. Chem. 2002, 45, 5483-5491.

132. Maletinska, L.; Spolcova, A.; Maixnerova, J.; Blechova, M.; Zelezna, B. Biological properties of prolactin-releasing peptide analogs with modified aromatic ring of C-terminal phenylalanine amide. Biopolymers 2011, 96, 481-481.

133. Gutierrez-Pascual, E.; Leprince, J.; Martinez-Fuentes, A.J.; Segalas-Milazzo, I.; Pineda, R.; Roa, J.; Duran-Prado, M.; Guilhaudis, L.; Desperrois, E.; Lebreton, A.; et al. In vivo and in vitro structure-activity relationships and structural conformation of kisspeptin-10-related peptides. Mol. Pharmacol. 2009, 76, 58-67.

134. Tomita, K.; Niida, A.; Oishi, S.; Ohno, H.; Cluzeau, J.; Navenot, J.M.; Wang, Z.X.; Peiper, S.C.; Fujii, N. Structure-activity relationship study on small peptidic GPR54 agonists. Bioorg. Med. Chem. 2006, 14, 7595-7603.

135. Niida, A.; Wang, Z.; Tomita, K.; Oishi, S.; Tamamura, H.; Otaka, A.; Navenot, J.M.; Broach, J.R.; Peiper, S.C.; Fujii, N. Design and synthesis of downsized metastin (45-54) analogs with maintenance of high GPR54 agonistic activity. Bioorg. Med. Chem. Lett. 2006, 16, 134-137.

136. Orsini, M.J.; Klein, M.A.; Beavers, M.P.; Connolly, P.J.; Middleton, S.A.; Mayo, K.H. Metastin (KISS-1) mimetics identified from peptide structure-activity relationship-derived pharmacophores and directed small molecule database screening. J. Med. Chem. 2007, 50, 462-471.

137. Clements, M.K.; McDonald, T.P.; Wang, R.; Xie, G.; O'Dowd, B.F.; George, S.R.; Austin, C.P.; Liu, Q. FMRFamide-related neuropeptides are agonists of the orphan G-protein-coupled receptor GPR54. Biochem. Biophys. Res. Commun. 2001, 284, 1189-1193.

138. Oishi, S.; Misu, R.; Tomita, K.; Setsuda, S.; Masuda, R.; Ohno, H.; Naniwa, Y.; Ieda, N.; Inoue, N.; Ohkura, S.; et al. Activation of neuropeptide FF receptors by kisspeptin receptor ligands. ACS Med. Chem. Lett. 2011, 2, 53-57.

139. Tomita, K.; Oishi, S.; Ohno, H.; Peiper, S.C.; Fujii, N. Development of novel G-protein-coupled receptor 54 agonists with resistance to degradation by matrix metalloproteinase. J. Med. Chem. 2008, 51, 7645-7649.

140. Tomita, K.; Oishi, S.; Cluzeau, J.; Ohno, H.; Navenot, J.M.; Wang, Z.X.; Peiper, S.C.; Akamatsu, M.; Fujii, N. SAR and QSAR studies on the N-terminally acylated pentapeptide agonists for GPR54. J. Med. Chem. 2007, 50, 3222-3228.

141. Tomita, K.; Narumi, T.; Niida, A.; Oishi, S.; Ohno, H.; Fujii, N. Fmoc-based solid-phase synthesis of GPR54-agonistic pentapeptide derivatives containing alkene- and fluoroalkene-dipeptide isosteres. Biopolymers 2007, 88, 272-278.

142. Curtis, A.E.; Cooke, J.H.; Baxter, J.E.; Parkinson, J.R.; Bataveljic, A.; Ghatei, M.A.; Bloom, S.R.; Murphy, K.G. A kisspeptin-10 analog with greater in vivo bioactivity than kisspeptin-10. Am. J. Physiol. Endocrinol. Metab. 2010, 298, E296-E303.

143. Ebling, F.J.; Luckman, S.M. RFamide-related peptide: Another sexy peptide? Endocrinology 2008, 149, 899-901.

144. Osugi, T.; Ukena, K.; Sower, S.A.; Kawauchi, H.; Tsutsui, K. Evolutionary origin and divergence of PQRFamide peptides and LPXRFamide peptides in the RFamide peptide family. Insights from novel lamprey RFamide peptides. FEBS J. 2006, 273, 1731-1743. 
145. Lagerstrom, M.C.; Fredriksson, R.; Bjarnadottir, T.K.; Fridmanis, D.; Holmquist, T.; Andersson, J.; Yan, Y.L.; Raudsepp, T.; Zoorob, R.; Kukkonen, J.P.; et al. Origin of the prolactin-releasing hormone (PRLH) receptors: Evidence of coevolution between PRLH and a redundant neuropeptide Y receptor during vertebrate evolution. Genomics 2005, 85, 688-703.

146. Malin, D.H.; Lake, J.R.; Leyva, J.E.; Hammond, M.V.; Rogillio, R.B.; Arcangeli, K.R.; Ludgate, K.; Moore, G.M.; Payza, K. Analog of neuropeptide FF attenuates morphine abstinence syndrome. Peptides 1991, 12, 1011-1014.

147. Malin, D.H.; Lake, J.R.; Smith, D.A.; Jones, J.A.; Morel, J.; Claunch, A.E.; Stevens, P.A.; Payza, K.; Ho, K.K.; Liu, J.; et al. Subcutaneous injection of an analog of neuropeptide FF prevents naloxone-precipitated morphine abstinence syndrome. Drug Alcohol. Depend. 1995, 40, 37-42.

148. Prokai, L.; Prokai-Tatrai, K.; Zharikova, A.; Li, X.; Rocca, J.R. Combinatorial lead optimization of a neuropeptide FF antagonist. J. Med. Chem. 2001, 44, 1623-1626.

149. Tan, P.P.; Chen, J.C.; Li, J.Y.; Liang, K.W.; Wong, C.H.; Huang, E.Y. Modulation of naloxone-precipitated morphine withdrawal syndromes in rats by neuropeptide FF analogs. Peptides 1999, 20, 1211-1217.

150. Doods, H.N.; Wieland, H.A.; Engel, W.; Eberlein, W.; Willim, K.D.; Entzeroth, M.; Wienen, W.; Rudolf, K. BIBP 3226, the first selective neuropeptide Y1 receptor antagonist: A review of its pharmacological properties. Regul. Pept. 1996, 65, 71-77.

151. Engstrom, M.; Wurster, S.; Savola, J.M.; Panula, P. Functional properties of Pfr(Tic)amide and BIBP3226 at human neuropeptide FF2 receptors. Peptides 2003, 24, 1947-1954.

152. Fang, Q.; Guo, J.; Chang, M.; Chen, L.X.; Chen, Q.; Wang, R. Neuropeptide FF receptors exert contractile activity via inhibition of nitric oxide release in the mouse distal colon. Peptides $\mathbf{2 0 0 5}$, 26, 791-797.

153. Mollereau, C.; Gouarderes, C.; Dumont, Y.; Kotani, M.; Detheux, M.; Doods, H.; Parmentier, M.; Quirion, R.; Zajac, J.M. Agonist and antagonist activities on human NPFF(2) receptors of the NPY ligands GR231118 and BIBP3226. Br. J. Pharmacol. 2001, 133, 1-4.

154. Iyengar, S.; Li, D.L.; Simmons, R.M., Characterization of neuropeptide Y-induced feeding in mice: Do Y1-Y6 receptor subtypes mediate feeding? J. Pharmacol. Exp. Ther. 1999, 289, 1031-1040.

155. Morgan, D.G.; Small, C.J.; Abusnana, S.; Turton, M.; Gunn, I.; Heath, M.; Rossi, M.; Goldstone, A.P.; O'Shea, D.; Meeran, K.; et al. The NPY Y1 receptor antagonist BIBP 3226 blocks NPY induced feeding via a non-specific mechanism. Regul. Pept. 1998, 75-76, 377-382.

156. Bourguignon, J.; Schmitt, M.; Becker, P. Dipeptide ligands of the NPFFreceptor for treating pain and hyperalgesia. WO Patent: WO/2002/024192, 2002.

157. Simonin, F.; Schmitt, M.; Laulin, J.P.; Laboureyras, E.; Jhamandas, J.H.; MacTavish, D.; Matifas, A.; Mollereau, C.; Laurent, P.; Parmentier, M.; et al. RF9, a potent and selective neuropeptide FF receptor antagonist, prevents opioid-induced tolerance associated with hyperalgesia. Proc. Natl. Acad. Sci. USA 2006, 103, 466-471.

158. Fang, Q.; Wang, Y.Q.; He, F.; Guo, J.; Chen, Q.; Wang, R. Inhibition of neuropeptide FF (NPFF)-induced hypothermia and anti-morphine analgesia by RF9, a new selective NPFF receptors antagonist. Regul. Pept. 2008, 147, 45-51. 
159. Jhamandas, J.H.; Simonin, F.; Bourguignon, J.J.; Harris, K.H. Neuropeptide FF and neuropeptide VF inhibit gabaergic neurotransmission in parvocellular neurons of the rat hypothalamic paraventricular nucleus. Am. J. Physiol. Regul. Integr. Comp. Physiol. 2007, 292, R1872-R1880.

160. Roussin, A.; Serre, F.; Gouarderes, C.; Mazarguil, H.; Roumy, M.; Mollereau, C.; Zajac, J.M. Anti-analgesia of a selective NPFF2 agonist depends on opioid activity. Biochem. Biophys. Res. Commun. 2005, 336, 197-203.

161. Synaptic Pharmaceuticals Corp; Kawakami, J.; Wetzel, J.; Boteju, L.; Konkel, M.; Wan, H.; Noble, S., Guanidines which are agonist/antagonist ligands for neuropeptide FF (NPFF) receptors. WO Patent: WO2003026667A1, 2003.

162. Caroff, E.; Steger, M.; Valdenaire, O.; Fecher, A.; Breu, V.; Hilpert, K.; Fretz, H.; Giller, T. Guanidine derivatives and use thereof as neuropeptide FF receptor antagonists. EP Patent: EP20040722212, WO Patent: WO2004083218, 2004.

163. Fecher, A.; Fretz, H.; Hilpert, K.; Breu, V.; Giller, T.; Valdenaire, O. Guanidine derivatives. WO Patent: WO2005023781, 2005.

164. Actelion Pharmaceuticals, L.; Caroff, E.R.; Steger, M.S.G.; Valdenaire, O.A.; Fecher, A.A.; Breu, V.S.; Hilpert, K.H.; Fretz, H.R.; Giller, T.W. Guanidine derivatives and their use as neuropeptide FF receptor antagonists. US Patent: US 7,727,979 B2, 2010.

165. Roseweir, A.K.; Kauffman, A.S.; Smith, J.T.; Guerriero, K.A.; Morgan, K.; Pielecka-Fortuna, J.; Pineda, R.; Gottsch, M.L.; Tena-Sempere, M.; Moenter, S.M.; et al. Discovery of potent kisspeptin antagonists delineate physiological mechanisms of gonadotropin regulation. $J$. Neurosci. 2009, 29, 3920-3929.

166. Pineda, R.; Garcia-Galiano, D.; Roseweir, A.; Romero, M.; Sanchez-Garrido, M.A.; Ruiz-Pino, F.; Morgan, K.; Pinilla, L.; Millar, R.P.; Tena-Sempere, M. Critical roles of kisspeptins in female puberty and preovulatory gonadotropin surges as revealed by a novel antagonist. Endocrinology 2010, 151, 722-730.

167. Kobayashi, T.; Sasaki, S.; Tomita, N.; Fukui, S.; Kuroda, N.; Nakayama, M.; Kiba, A.; Takatsu, Y.; Ohtaki, T.; Itoh, F.; et al. Synthesis and structure-activity relationships of 2-acylamino-4,6-diphenylpyridine derivatives as novel antagonists of GPR54. Bioorg. Med. Chem. 2010, 18, 3841-3859.

168. Kobayashi, T.; Sasaki, S.; Tomita, N.; Fukui, S.; Nakayama, M.; Kiba, A.; Kusaka, M.; Matsumoto, S.; Yamaguchi, M.; Itoh, F.; et al. 2-acylamino-4,6-diphenylpyridine derivatives as novel GPR54 antagonists with good brain exposure and in vivo efficacy for plasma LH level in male rats. Bioorg. Med. Chem. 2010, 18, 5157-5171.

169. Lameh, J.; Bertozzi, F.; Kelly, N.; Jacobi, P.M.; Nguyen, D.; Bajpai, A.; Gaubert, G.; Olsson, R.; Gardell, L.R. Neuropeptide FF receptors have opposing modulatory effects on nociception. $J$. Pharmacol. Exp. Ther. 2010, 334, 244-254.

(C) 2011 by the authors; licensee MDPI, Basel, Switzerland. This article is an open access article distributed under the terms and conditions of the Creative Commons Attribution license (http://creativecommons.org/licenses/by/3.0/). 